\title{
Geoinformatics for assessing the morphometric control on hydrological response at watershed scale in the Upper Indus Basin
}

\author{
Shakil Ahmad Romshoo*, Shakeel Ahmad Bhat and Irfan Rashid \\ Department of Geology and Geophysics, University of Kashmir, Hazratbal, Srinagar Kashmir 190 006, India. \\ ${ }^{*}$ Corresponding author.e-mail: shakilrom@yahoo.com
}

Five watersheds (W1, W2, W3, W4 and W5) in the upper Indus basin were chosen for detailed studies to understand the influences of geomorphology, drainage basin morphometry and vegetation patterns on hydrology. From the morphometric analysis, it is evident that the hydrologic response of these watersheds changes significantly in response to spatial variations in morphometric parameters. Results indicate that W1, W2 and W5 contribute higher surface runoff than W3 and W4. Further, the topographic and land cover analyses reveal that W1, W2 and W5 generate quick runoff that may result in flooding over prolonged rainy spells. A physically based semi-distributed hydrologic model (soil and water assessment tool, SWAT) was used for simulating the hydrological response from the watersheds. As per the simulations, W5 watershed produces the highest runoff of $11.17 \mathrm{~mm} /$ year followed by W1 $(7.9 \mathrm{~mm} /$ year$)$, W2 $(6.6 \mathrm{~mm} /$ year $)$, W4 (5.33 mm/year) and W3 $(4.29 \mathrm{~mm} /$ year $)$. Thus, W5 is particularly more vulnerable to flooding during high rain spells followed by W1, W2, W4 and W3, respectively. Synthetic unit hydrograph analysis of the five watersheds also reveals high peak discharge for W5. The simulated results on the hydrological response from the five watersheds are quite in agreement with those of the morphometric, topographic, vegetation and unit hydrograph analyses. Therefore, it is quite evident that these factors have significant impact on the hydrological response from the watersheds and can be used to predict flood peaks, sediment yield and water discharge from the ungauged watersheds.

\section{Introduction}

At the global level, flooding is the single most destructive type of natural disaster that strikes humans and their livelihoods around the world (UN 2004). The impacts of flood hazards on a global scale are enormous (Ahern et al 2005; Berz et al 2001; Hajat et al 2003; Jonkman 2005; Jonkman and Vrijling 2008). Flooding is responsible for more than one-third of the total estimated costs incurred due to disasters and is responsible for two-thirds of the people affected by natural disasters (Coates 1999; Jonkman and Kelman 2005;
Jonkman 2005; Munich Re 2007; UN 2004). Spatial and temporal dimensions of this threat have driven the current international and national concerns on how to lessen the consequences of flood hazards and human losses. In the last decade, there have been catastrophic flooding events all over the globe. The main reasons for the observed increase in flood disasters are an increase in the global temperature due to the effects of climate change (IPCC 2007); population growth and migration of population to coastal areas and river valleys; overexploitation of natural resources, deforestation, growing urbanization and uncontrolled land

Keywords. Digital elevation model; geospatial modelling; hydrology; morphometry; remote sensing; geoinformatics. 
use change. Flooding is not restricted to the least developed nations, but also occurs in a devastating manner in the most developed and industrialized countries of the world. However, it is the citizens of the least developed nations that suffer the highest toll from flooding. India, being one of the developing countries where floods and other natural disasters are one of the serious geo-hazards, has witnessed alarmingly increased floods in recent times due to number of complex factors related to topography, geology, climate and human activity. About 40 million hectares or nearly $1 / 8$ th of India's geographical area is flood-prone (Bapalu and Sinha 2005). Among the physiographic divisions of India, the Himalayas have the greatest sub-areal maximum relief, torrential rainstorms, frequent cloud bursts and a history of floods augmented by melting glaciers and river action. The floods thus pose a major physical threat to the sustainable development in the Himalayas (Jack 2004). The available data suggests that during the period 1954-1990, more than ₹ 2700 billion were spent on the flood control measures in India, but the annual flood damage increased by nearly 40 times and the annual flood affected areas increased by 1.5 times in this period (Agarwal and Narain 1996). Among the various hazard-prone Himalayan states of India, Jammu and Kashmir is more vulnerable to almost all the hazards. The historical records reveal that the Kashmir Himalayan region has suffered heavy causalities and loss of property due to floods, avalanches and other hydrometeorological disasters.

Flooding results from climatological events such as excessive and/or prolonged rainfall, including snow and ice melt, cloud burst, failure of dams and storm surges. Floods can be intensified by factors associated either with the catchment itself or with the drainage network and stream channels (Ward and Robinson 2000). Furthermore, there exist a number of factors that can further affect the process of flooding (Gardiner 1981). Such factors can be human or physical or both, and will exert dominant controls to either intensify or ameliorate a flooding event. Topography is recognized as a first-order control on the hydrological response of a catchment to rainfall (Brasington and Richards 1998) and is a major determinant for flood inundation (Bates and De Roo 2000). Similarly, morphological characteristics such as stream order, drainage density, channel slope, relief, length of overland flow, stream frequency and other morphological aspects of watershed are important in understanding the hydrology of the watershed (Chow 1964; Strahler 1964; Ward and Robinson 2000; Hudson and Colditz 2003). Runoff response of the watershed is different for different slopes, shapes, lengths, widths and areas of watershed.
Natural features such as land use and land cover, soil and geology that have significant influence upon the characteristics of a catchment hydrograph, need to be considered, for understanding flood mechanisms. This is largely related to the permeability, transmissibility and water storage of the catchment (Barry and Chorley 1998; Robinson et al 2000; Ward and Robinson 2000). Deforestation can lead to increased risk and magnitude of flood inundation (Bosch and Hewlett 1982; Arnell 2002). It is therefore very important to quantify the geomorphic, morphological and topographic characteristics of a watershed accurately in order to aid in analysing the hydrologic response of watersheds.

Even though there is growing interest in carrying out research on natural disasters among geoscientists, there is still a significant gap in our understanding of the factors associated with flood hazard vulnerability (Beven 1989). This research therefore addresses the fundamental scientific question of assessing the geologic and hydrological factors that make a drainage basin more or less prone to flooding. In this research, an integrated analysis of the hydrological, morphological and geomorphometrical properties of five watersheds of the Jhelum River basin facilitated a better understanding of the flooding problem and its associated processes. The advancement in the field of satellite remote sensing, geographic information system (GIS), simulation modelling and advanced field observation techniques have facilitated a better understanding of the geomorphological and geological influences on hydrology. Remote sensing data was used to generate up-to-date information about different hydrological and geomorphological parameters. Simulation models and geospatial techniques were used to simulate the hydrological processes. Thus, the findings can be of tremendous practical use in planning flood management and mitigation strategies. The contents of this paper are organized into various sections such as introduction, study area, methods, results, discussion and conclusions.

\section{Study area}

The Jhelum basin is elongated in shape and bounded between the Zanaskar (Greater Himalayas) and Pir Panjal mountain ranges between $33^{\circ} 21^{\prime} 52^{\prime \prime}-$ $34^{\circ} 41^{\prime} 33^{\prime \prime} \mathrm{N}$ latitude and $74^{\circ} 07^{\prime} 55^{\prime \prime}-75^{\circ} 29^{\prime} 57^{\prime \prime} \mathrm{E}$ longitude. River Jhelum passes largely along the middle of the Kashmir valley through the alluvium of its own deposition. The basin is the recipient of the entire drainage of the valley and is known in Kashmir by the name 'VYATH'. The river comprises fairly developed streams as well as 


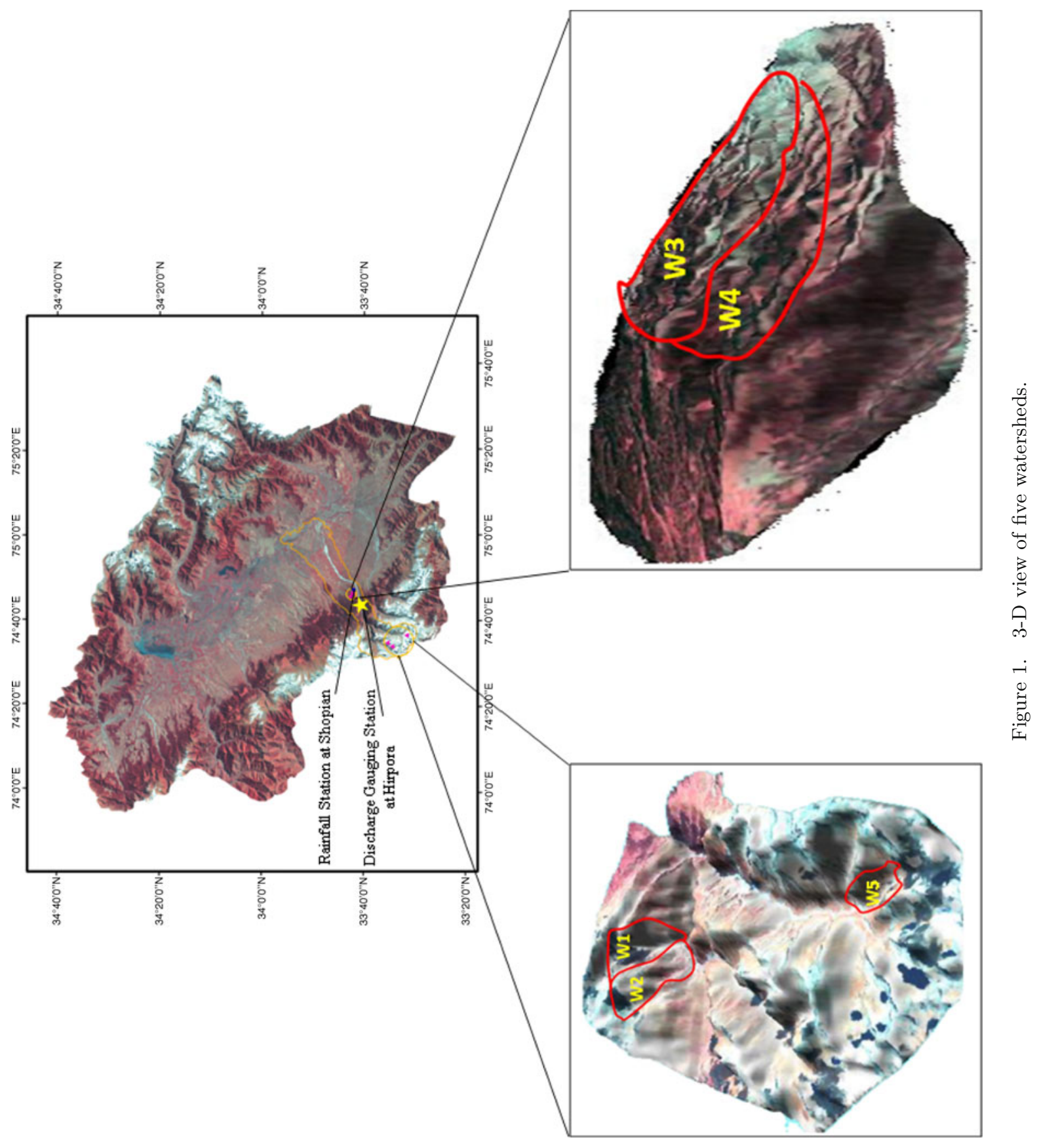


tiny rivulets with quite remarkable variations in the drainage and catchment characteristics. The Jhelum basin has 24 tributaries and some of them drain from the slopes of the Pir Panjal range and join the river on the left bank; while others flow from the Himalayan range and join the river on the right bank. So, the Jhelum basin has 24 catchments and these have been subdivided into 60 subcatchments. The hydrographic features and drainage characteristics of Jhelum river system show that the frequency of floods has been very high ever since the valley assumed its present form. There have been almost more than 25 major floods and mean expectancy being 1 in 4.3 years (Moonis et al 1975). The valley being saucershaped with steep mountain slopes around, any heavy rain spell for duration of 1-2 days can cause serious floods (Dhar et al 1982). In general, the layout of Kashmir valley is such that it is highly prone to flooding. Also, the growth of human population and horizontal expansion of settlements and encroachments on the water courses, reclamation of low-lying areas for agriculture, channelizing of rivers, construction of roads along river banks and urbanization of the flood plains, have aggravated flood risk in the Jhelum basin. In order to accomplish the research objectives, five watersheds in the upstream of Jhelum basin, herein referred as W1 (long. $74^{\circ} 32^{\prime}-74^{\circ} 36^{\prime} \mathrm{E}$, lat. $33^{\circ} 40^{\prime}-33^{\circ} 43^{\prime} \mathrm{N}$ ), W2 (long. $74^{\circ} 32^{\prime}-74^{\circ} 33^{\prime} \mathrm{E}$, lat. $33^{\circ} 39^{\prime}-33^{\circ} 40^{\prime} \mathrm{N}$ ), W3 (long. $74^{\circ} 43^{\prime}-74^{\circ} 46^{\prime} \mathrm{E}$, lat. $33^{\circ} 41^{\prime}-33^{\circ} 44^{\prime} \mathrm{N}$ ), W4 (long. $74^{\circ} 42^{\prime}-74^{\circ} 46^{\prime} \mathrm{E}$, lat. $33^{\circ} 41^{\prime}-33^{\circ} 44^{\prime} \mathrm{N}$ ) and W5 (long. $74^{\circ} 32^{\prime}-74^{\circ} 35^{\prime} \mathrm{E}$, lat. $33^{\circ} 33^{\prime}-33^{\circ} 34^{\prime} \mathrm{N}$ ), respectively, with an areal extent of $12.44,11.97$, $10.64,11.58$ and $10.83 \mathrm{~km}^{2}$, respectively, were selected for detailed geomorphometric, hydrological, vegetation and climatological analyses. Figure 1 shows the three-dimensional (3-D) view of these five watersheds.

\section{Methods}

In order to accomplish the set research objectives, it is important to use a host of methods that includes the use of satellite remote sensing data, detailed field observations, hydrological data, digital elevation data, secondary/ancillary data, geospatial tools and simulation models. The details of the methodology adopted for accomplishing the research objectives are briefly discussed here.

\subsection{Morphometry}

Morphometry deals with the quantitative study of the area, altitude, volume, slope, profiles of the land and drainage basin characteristics of the area concerned (Clarke 1966; Singh 1972a, 1972b; Strahler 1964). The application of geomorphic principles to understand and quantify environmental hazards such as flooding has led to a significant amount of research focused on identifying the relationships between basin morphometry and stream flooding (Patton 1988). In order to understand the geomorphological influences on the flooding, it is essential to study the morphometry and relate it to the hydrology of the basins (Rakesh 2000). Therefore, five watersheds with varied topographic, hydrologic, vegetation and physiographic setting were chosen for detailed morphometric analyses to understand the geomorphological and hydrological linkages.

However, it has been recognized that generating information about important basin parameters using traditional methods based on map measurements is labour-intensive and tedious. Other than a few parameters that can be easily measured from maps such as elevation and relief; measurement of more complex parameters such as stream length, drainage density, mean basin elevation and channel gradient for streams of different orders has been hampered by the amount of time that must be dedicated to extract these parameters from maps. Therefore, digital elevation models (DEM) in GIS environment were used to compute these morphometric characteristics with greater efficiency and accuracy. Geospatial techniques have gained significant importance over the last decade in their applications pertaining to drainage morphological characteristics (Band 1986; Mark 1988; Tarboton 1989; Lawrence and Jurgen 1993; Al-Wagdany and Rao 1994; Garbrecht and Martz 1997; Bhat and Romshoo 2008). The specific methods and steps followed for the generation of morphometric parameters are shown schematically in figure 2 .

DEM is a representation of the continuous variation of relief over space and there are several possible methods for generating DEM. We used the existing 1:50,000 scale topographic maps with $20 \mathrm{~m}$ contours to generate DEM (Oky et al 2002). Due to nonavailability of high resolution stereoimaging data for generation of DEM we preferred the existing topographic maps. DEMs at $20 \mathrm{~m}$ resolution were generated from the digitized contours at watershed level using inverse distance weighted (IDW) interpolation technique (Burrough 1986). The process involved various steps (Band 1986; Tarboton and Shankar 1998; Bhat and Romshoo 2008). Various workers have used DEMs for extracting morphometric features (Mark 1988; Tarboton et al 1991, 1992; Tarboton 1997; Tarboton and Ames 2001). After the processing of the digital elevation models, the morphometric parameters were extracted using the mathematic formulations as described in table 1. 


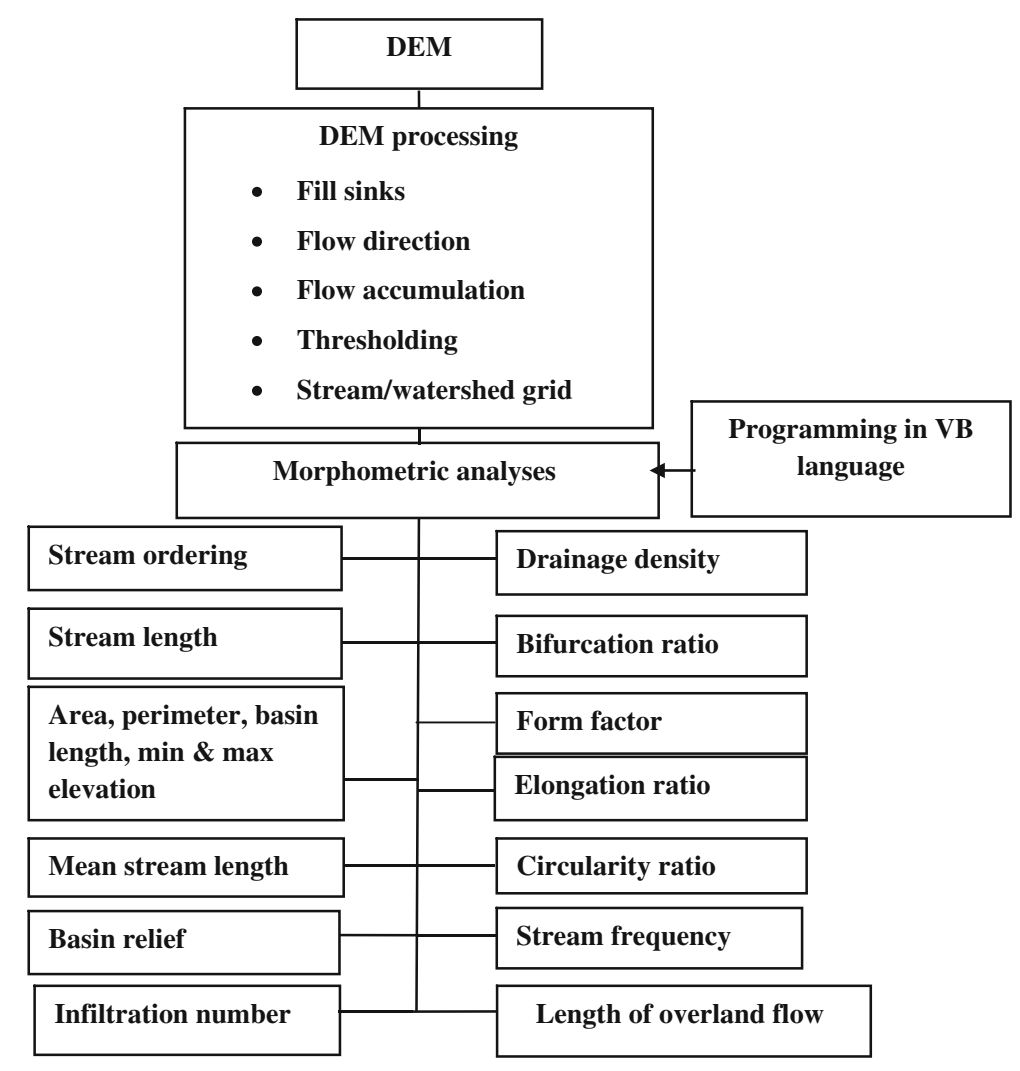

Figure 2. Flow chart of methodology used for morphometric analysis.

\subsection{Synthetic unit hydrograph model}

Clark (1945) pioneered hydrologic modelling approach with his unit hydrograph technique that uses three main components: time of concentration, a storage coefficient and a time-area histogram (Kull and Feldman 1998). Clark's synthetic unit hydrograph methodology involves the application of a unit excess rainfall $(1 \mathrm{~mm})$ over the watershed. The precipitation is conveyed to the basin outlet by a translation hydrograph and linear reservoir routing. For this purpose, the time of concentration value $(T c)$, the storage attenuation coefficient $(R)$ and the time area histogram of the basin are necessary. The representative watersheds were subdivided into time-area increments by estimating the time of travel to various locations within the drainage network and constructing isochrones (Timothy et al 2000). The area representing each increment of time was measured, and the total volume represented by 1 inch of runoff from that increment was calculated. Dividing that by the time interval between the isochrones, it yields a volumetric flow rate, which is plotted against the travel time represented by the isochrones. In this way, the sequence of flows resulting from the instantaneous generation of 1 inch of runoff from all time-area increments is created. All these steps were carried out in the GIS environment using DEM (Band 1986; Mark 1988).

\subsection{Simulating hydrological processes}

For understanding the interactions between the climatic, terrestrial, topographic and hydrological elements; hydrological response of the five unguaged watersheds was simulated using geospatial hydrological modelling approach. A number of research studies have been conducted under varied hydrological and geomorphological conditions using geospatial simulation models to quantify the hydrological processes at various spatial scales (DeVantier and Feldman 1993; Olivera and Maidment 1996; Jain and Sinha 2003; Gorokhovich et al 2000; Saghafian et al 2000). In order to quantify the hydrological processes in the five representative watersheds, we used GIS-based soil and water assessment tool (SWAT) model (Arnold et al 1998). SWAT is a physically based basin-scale, continuous time, distributed parameter hydrologic model that uses spatially distributed data on soil, land use, DEM and weather for hydrologic modelling and operates on a daily time step. Major model components include weather, hydrology, soil type, soil temperature and land management. For spatially explicit 
Table 1. Equations and description of the morphometric parameters.

\begin{tabular}{|c|c|c|}
\hline Parameters & Equation & Description \\
\hline Watershed area $\left(\mathrm{km}^{2}\right)$ & $A=a \times n \times 10^{-6}$ & $\begin{array}{l}a: \text { cell area }\left(\mathrm{m}^{2}\right) \\
n: \text { number of watershed cells }\end{array}$ \\
\hline Watershed perimeter $(\mathrm{km})$ & $P=d \times n_{p} \times 10^{-3}$ & $\begin{array}{l}d: \text { cell size }(\mathrm{m}) \\
n_{p}: \text { number of watershed edge cells }\end{array}$ \\
\hline Watershed length (m) & $L_{b}$ & $L_{b}=$ farthest distance from watershed ridge to outlet \\
\hline Slope & $S=\frac{\mathrm{DE}}{L}$ & $\begin{array}{l}S=\text { slope } \\
\mathrm{DE}=\text { difference in elevation } \\
L=\text { length of the flow path }\end{array}$ \\
\hline Stream length & $\bar{L}_{u}=\sum_{i=1}^{N} L_{u}$ & $\begin{array}{l}\bar{L}_{u}=\text { mean length of channel } \\
L_{u}=\text { stream-channel segment of order } u\end{array}$ \\
\hline Stream length ratio & $\mathrm{RL}=L_{u} /\left(L_{u}-1\right)$ & $\begin{array}{l}\mathrm{RL}=\text { stream length ratio } \\
L_{u}=\text { the total stream length of order } u \\
L_{u}-1=\text { the total stream length of preceding stream order }\end{array}$ \\
\hline Drainage density & $D_{d}=\sum L_{u} / A_{u}$ & $\begin{array}{l}D_{d}=\text { drainage density } \\
L_{u}=\text { total stream length } \\
A_{u}=\text { basin area }\end{array}$ \\
\hline Stream frequency & $F_{s}=\sum N_{u} / A_{u}$ & $\begin{array}{l}F_{s}=\text { stream frequency } \\
N_{u}=\text { number of stream segments } \\
A_{u}=\text { basin area }\end{array}$ \\
\hline Bifurcation ratio & $R_{b}=\left(N_{u}\right) /\left(N_{u}+1\right)$ & $\begin{array}{l}R_{b}=\text { bifurcation ratio } \\
N_{u}=\text { number of stream segments }\end{array}$ \\
\hline Length of overland flow & $L_{g}=0.5 / D_{d}$ & $\begin{array}{l}L_{g}=\text { length of over flow } \\
D_{d}=\text { drainage density }\end{array}$ \\
\hline Form factor & $R_{f}=\left(A_{u}\right) /\left(L_{b}+1\right)^{2}$ & $\begin{array}{l}R_{f}=\text { form factor } \\
A_{u}=\text { basin area } \\
L_{b}=\text { farthest distance from watershed ridge to outlet }\end{array}$ \\
\hline Elongation ratio & $R_{e}=\frac{2}{\pi} \sqrt{\frac{A_{u}}{\left(L_{b}\right)^{2}}}$ & $\begin{array}{l}R_{e}=\text { elongation ratio } \\
\pi=3.14 \\
A_{u}=\text { basin area } \\
L_{b}=\text { farthest distance from watershed ridge to outlet }\end{array}$ \\
\hline Circularity ratio & $R_{c}=4 \pi A_{u} /\left(A_{u}\right)^{2}$ & $\begin{array}{l}R_{c}=\text { circularity ratio } \\
A_{u}=\text { basin area }\end{array}$ \\
\hline Infiltration number & $I_{f}=D_{d} \times F_{s}$ & $\begin{array}{l}I_{f}=\text { infiltration number } \\
F_{s}=\text { stream frequency }\end{array}$ \\
\hline
\end{tabular}

parameterization, SWAT subdivides watersheds into sub-basins based on topography, which are further subdivided into hydrologic response units (HRU) based on unique soil and land-use characteristics. SWAT can simulate surface runoff using either the modified SCS curve number (CN) method (USDA-SCS, 1972) or the Green-Ampt infiltration model based on an infiltration excess approach (Green and Ampt 1911) depending on the availability of daily or hourly precipitation data, respectively. The SCS curve number method was used in this study with daily precipitation data. Based on the soil hydrologic group, vegetation type and land management practice; initial CN values are assigned from the SCS Hydrology
Handbook (USDA-SCS 1972). SWAT updates the $\mathrm{CN}$ values daily based on changes in soil moisture. The excess water available after accounting for initial abstractions and surface runoff, using the SCS CN method, infiltrates into the soil. A storage routing technique is used to simulate the flow through each soil layer. SWAT directly simulates saturated flow only and assumes that water is uniformly distributed within a given layer. Unsaturated flow between layers is indirectly modelled using depth distribution functions for plant water uptake and soil water evaporation. Downward flow occurs when the soil water in the layer exceeds field capacity and the layer below is not saturated. The rate of downward flow is governed by 
the saturated hydraulic conductivity. Lateral flow in the soil profile is simulated using a kinematic storage routing technique that is based on slope, slope length and saturated conductivity. Upward flow from a lower layer to the upper layer is regulated by the soil water to field capacity ratios of the two layers. The hydrological cycle, simulated by SWAT model, is based on the water balance equation given below:

$\mathrm{SW}_{\mathrm{t}}=\mathrm{SW}_{0}+\sum_{i=1}^{t}\left(R_{\mathrm{day}}-Q_{\mathrm{surf}}-E_{\mathrm{a}}-w_{\mathrm{seep}}-Q_{\mathrm{gw}}\right)$,

where $\mathrm{SW}_{\mathrm{t}}$ is the final soil water content $(\mathrm{mm}$ $\left.\mathrm{H}_{2} \mathrm{O}\right), \mathrm{SW}_{0}$ is the initial soil water content on day $i$ $\left(\mathrm{mm} \mathrm{H}_{2} \mathrm{O}\right), t$ is the time (days), $R_{\text {day }}$ is the amount of precipitation on day $i\left(\mathrm{~mm} \mathrm{H}_{2} \mathrm{O}\right), Q_{\text {surf }}$ is the amount of surface runoff on day $i\left(\mathrm{~mm} \mathrm{H}_{2} \mathrm{O}\right), E_{\mathrm{a}}$ is the amount of evapotranspiration on day $i(\mathrm{~mm}$ $\left.\mathrm{H}_{2} \mathrm{O}\right), w_{\text {seep }}$ is the amount of water entering the vadose zone from the soil profile on day $i$ ( $\mathrm{mm}$ $\mathrm{H}_{2} \mathrm{O}$ ), and $Q_{\mathrm{gw}}$ is the amount of return flow on day $i\left(\mathrm{~mm} \mathrm{H}_{2} \mathrm{O}\right)$.

\subsubsection{SWAT model input data generation}

Input data for SWAT was generated using remote sensing, field, lab and hydrometeorological observations. The various input parameters and the methods of their generation are described here.

3.3.1a Topographical data: Topographical information required for the SWAT model was generated from DEM. The various topographical parameters required for the model are drainage network, aspect, slope, flow length, flow accumulation, flow direction, etc. All these parameters were generated in a GIS environment using standard methods (Band 1986; Mark 1988; Tarboton et al 1991; Tarboton 2000).

3.3.1b Hydrometeorological data: SWAT model requires daily precipitation, maximum and minimum air temperature, solar radiation, wind speed and relative humidity. Therefore, 20-year time series of meteorological data (1979-1999) from six rainfall stations, one temperature recording station and one river gauging station observation station, was statistically analysed to generate these parameters as per the requirements of the model. A number of secondary hydrometeorological parameters required as input for the SWAT model were generated using different mathematical formulations as shown in table 2 . Table 3 shows the monthly averages of all the hydrometeorological variables used as input to the SWAT model for simulating the hydrological processes. To generate the spatial distribution of the rainfall in the study area, mean monthly and average yearly values were interpolated in GIS by using IDW method (Burrough 1986). This technique determines cell values using a linearly weighted combination of a set of sample points. The weightage is a function of inverse distance.

3.3.1c Land use/land cover data: Information about land use and land cover is vital for several land surface processes including hydrological and climatic processes and therefore it is a very important data input for the SWAT model. Remote sensing has a long and successful history of application in generating land use and land cover information on operational basis (Hansen et al 1996; Foody 2002). For generating land use/land cover information for the representative watersheds, we used Landsat ETM digital data of September 2001. The satellite image was pre-processed to rectify the geometric distortions in order to improve its interpretability (Lillesand and Kiefer 1987). Thirty ground control points were taken from different parts of the study area for precise geometric correction using Universal Tranverse Mercator (UTM) coordinate system with World Geodetic System (WGS) 84 datum achieving root mean square error (RMSE) of 1.06 pixels. Various image enhancement techniques were also performed on the image for enhancing visual interpretability of the data. The corrected satellite data was then processed for land use and land cover classification using maximum likelihood supervised classification algorithm ( Fu 1976). While choosing various training samples for known land cover types, various image enhancement techniques were applied for homogenous and better choice taking into consideration the ground truth information. The land use and land cover map was validated in the field to determine its accuracy. The accuracy estimation is essential to assess reliability of the classified map. The ideal number of sample points chosen (64) for assessing the accuracy of the classification map was determined using binomial probability theory (Jensen 1996).

3.3.1d Soil data input: The information about soil is very vital for estimating the hydrological response at the watershed scale. The SWAT model requires detailed soil information on the type, properties and other geophysical characteristics. The methods employed for generating the 


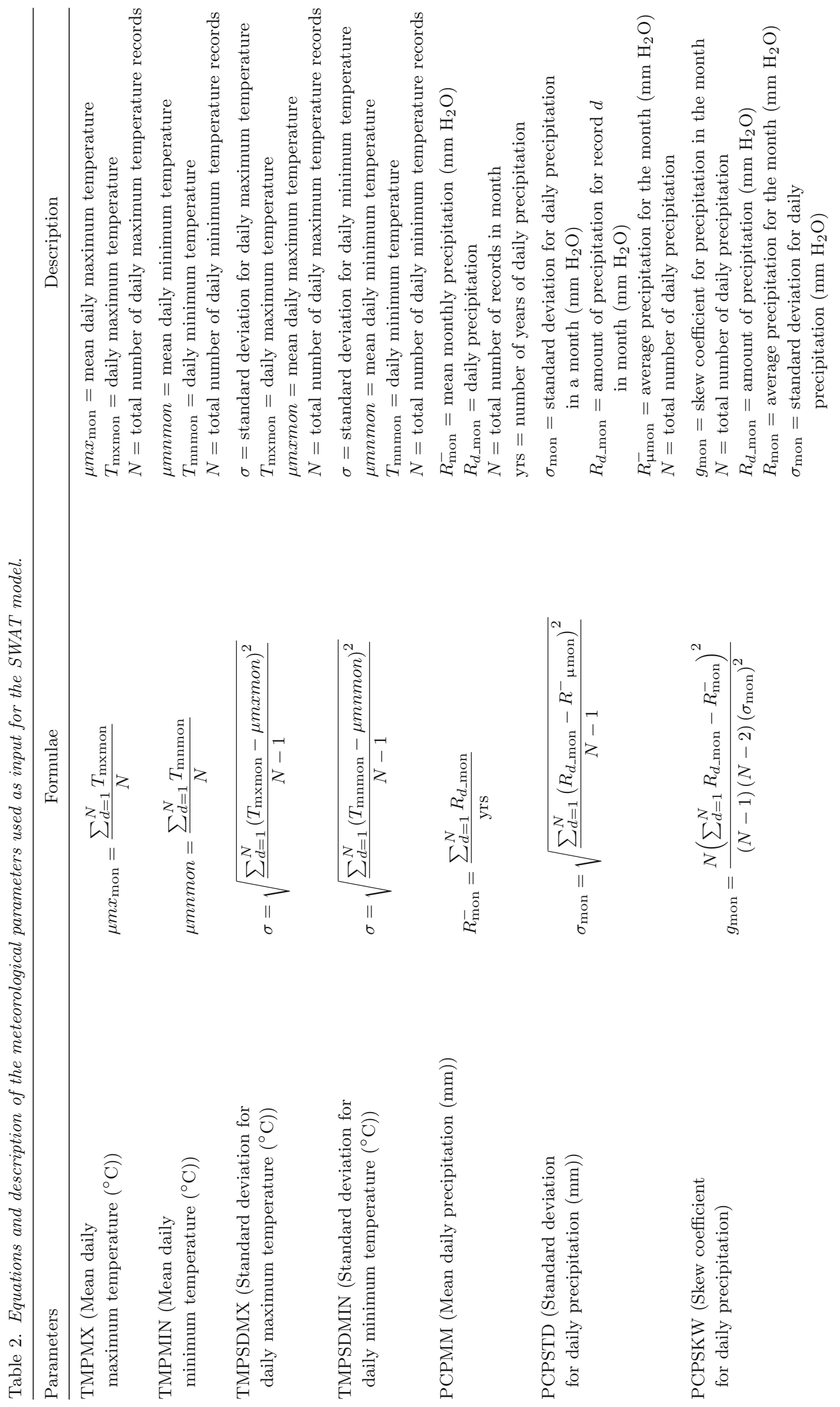




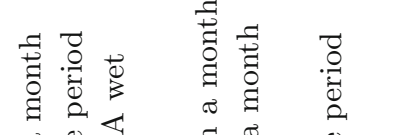

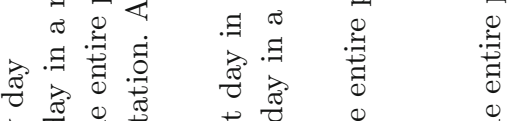

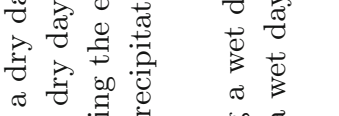

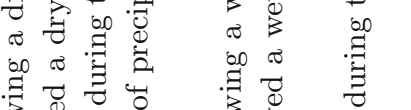

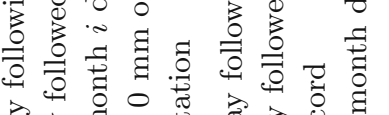 \\ ‡心

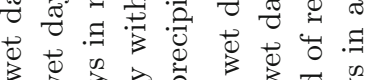

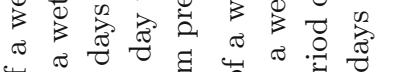

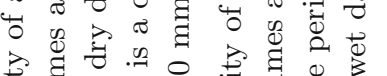

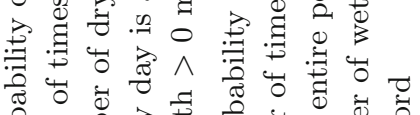

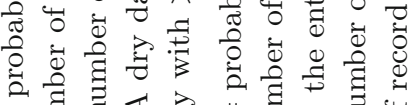

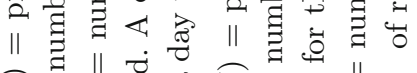

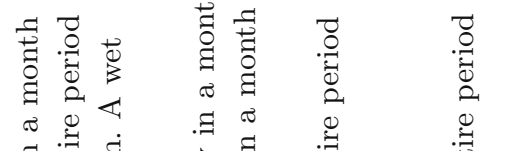

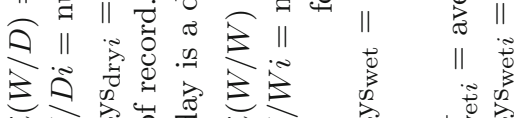

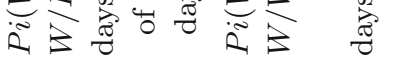

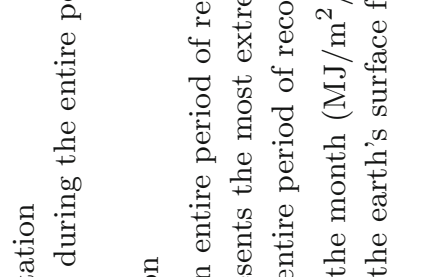

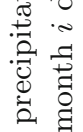

虫.

晃管

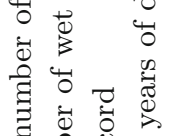

¿

苛范范

节

$0^{3}$

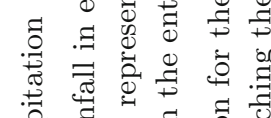

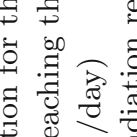

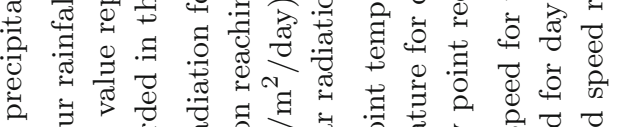
خ

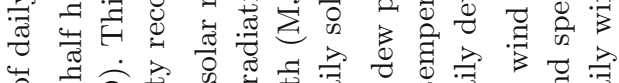

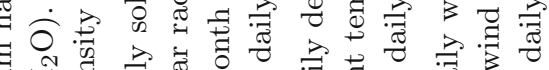

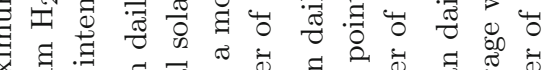

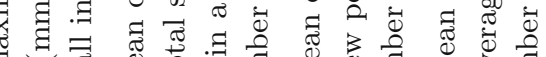

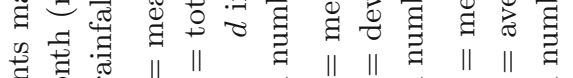

ర్ $\|$ वैं

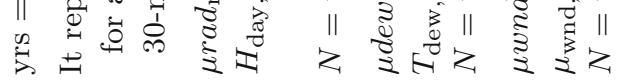

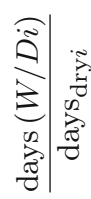

$\overbrace{}^{110}$

in
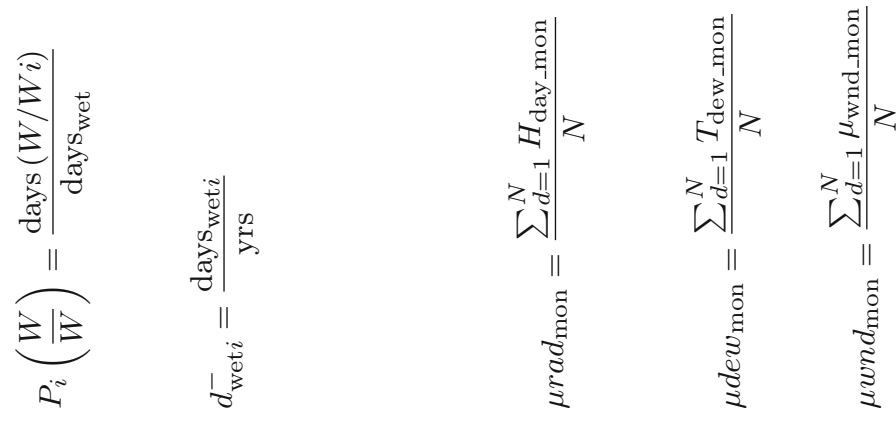

3
0
0
0
0
0
0
0
0
0
0
0
0
0
0
0
0
0
0
0
0
0
0
0
3
0
0
0

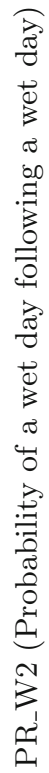

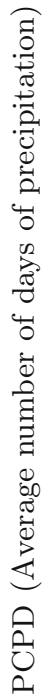

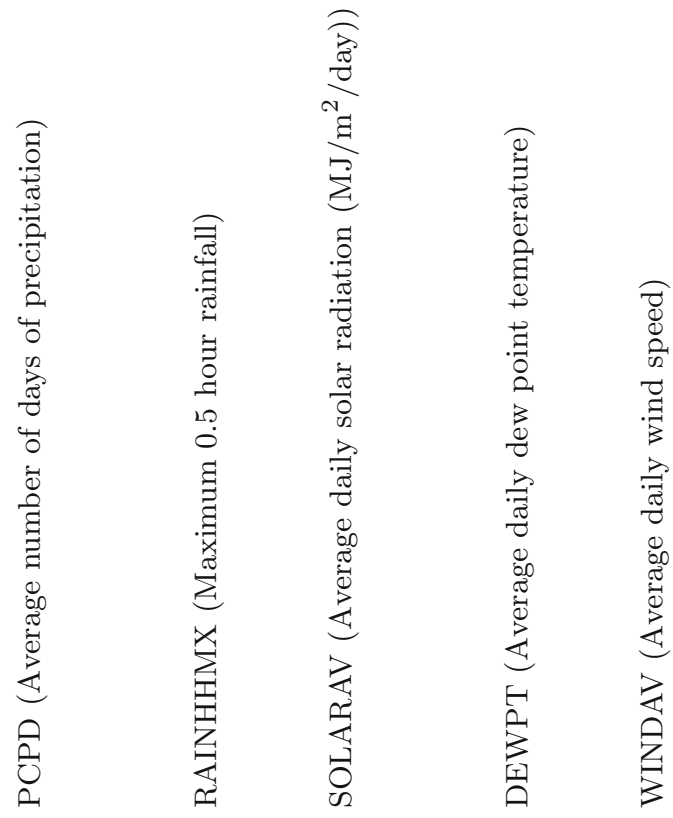


Table 3. Long term weather statistics used for generating input for the SWAT model (daily average of 20 years, 1979-1999).

\begin{tabular}{|c|c|c|c|c|c|c|c|c|c|c|c|c|}
\hline Jan & Feb & Mar & April & May & June & July & Aug & Sep & Oct & Nov & Dec & Parameters \\
\hline 4.56 & 8.59 & 12.34 & 18.14 & 23.44 & 26.34 & 29.59 & 28.49 & 27.92 & 20.81 & 19.07 & 7.67 & TMPMX \\
\hline-6.77 & -0.28 & 2.93 & 6.15 & 9.78 & 13.23 & 17.28 & 16.52 & 12.55 & 5.25 & 1.67 & -0.56 & TMPMIN \\
\hline 4.08 & 3.31 & 3.83 & 4.32 & 4.90 & 3.73 & 3.43 & 3.59 & 3.42 & 3.63 & 29.54 & 3.24 & TMPSDMX \\
\hline 4.21 & 2.14 & 2.45 & 2.35 & 2.53 & 1.78 & 2.31 & 2.04 & 3.23 & 2.49 & 1.79 & 2.47 & TMPSDMIN \\
\hline 1.31 & 1.88 & 4.38 & 3.46 & 2.67 & 1.81 & 2.17 & 2.53 & 1.35 & 1.31 & 0.59 & 0.77 & PCPMM \\
\hline 5.03 & 18.14 & 6.85 & 8.18 & 6.58 & 3.05 & 6.23 & 9.38 & 3.89 & 6.37 & 1.91 & 4.43 & PCPSTD \\
\hline 4.71 & 4.28 & 3.78 & 1.90 & 3.51 & 5.41 & 6.48 & 5.57 & 2.62 & 7.63 & 4.47 & 8.63 & PCPSKW \\
\hline 0.06 & 0.10 & 0.21 & 0.20 & 0.18 & 0.13 & 0.17 & 0.16 & 0.09 & 0.07 & 0.05 & 0.06 & PR_W1 \\
\hline 0.60 & 0.61 & 0.61 & 0.62 & 0.63 & 0.52 & 0.59 & 0.58 & 0.66 & 0.67 & 0.65 & 0.63 & PR_W2 \\
\hline 3.84 & 5.73 & 10.26 & 10.26 & 10.05 & 6.21 & 9.05 & 8.36 & 6.36 & 5.26 & 3.89 & 4.21 & PCPD \\
\hline 4.80 & 8.90 & 5.10 & 6.30 & 6.30 & 7.10 & 24.40 & 16.80 & 9.70 & 6.30 & 5.80 & 3.60 & RAINHHMX \\
\hline 8.75 & 11.30 & 12.06 & 14.87 & 17.04 & 19.28 & 17.46 & 17.82 & 17.93 & 16.15 & 13.44 & 10.01 & SOLARAV \\
\hline-7.51 & -6.75 & -6.86 & -5.21 & -3.56 & -1.38 & 7.35 & 8.74 & 5.13 & -1.09 & -4.94 & -6.89 & DEWPT \\
\hline 2.01 & 2.64 & 3.32 & 3.40 & 2.82 & 2.41 & 1.89 & 1.48 & 1.90 & 1.74 & 2.01 & 2.09 & WINDAV \\
\hline
\end{tabular}

Note: TMPMX - mean daily maximum temperature $\left({ }^{\circ} \mathrm{C}\right)$; TMPMIN - mean daily minimum temperature $\left({ }^{\circ} \mathrm{C}\right)$; $\mathrm{TMPS}-$ DMX - standard deviation for daily maximum temperature $\left({ }^{\circ} \mathrm{C}\right)$; TMPSDMIN - standard deviation for daily minimum temperature $\left({ }^{\circ} \mathrm{C}\right)$; PCPMM - mean daily precipitation $(\mathrm{mm})$; PCPSTD - standard deviation for daily precipitation (mm); PCPSKW - skew coefficient for daily precipitation; PR_W1 - probability of a wet day following a dry day; PR_W2 probability of a wet day following a wet day; PCPD - average number of days of precipitation; RAINHHMX - maximum 0.5 hour rainfall; SOLARAV - average daily solar radiation (MJ/m2/day); DEWPT - average daily dew point temperature; WINDAV - average daily wind speed.

soil map involved field observation, lab analysis and the remote sensing data (Khan and Romshoo 2008). Visual interpretation of Landsat ETM September 2001 image was carried out and different soil classes delineated on the basis of tone, texture, shape and associated land cover types and various other image elements that aided soil interpretation. A series of field surveys were conducted for validation of identified soil classes from the satellite image. Soil samples from each identified classes were collected for the soil texture analyses in the lab. Composite soil samples up to $15 \mathrm{~cm}$ depth were collected for each soil class. About 2-3 samples were collected from each identified soil class for the lab analysis for determining the soil texture. In all, 36 composite soil samples were analysed for soil texture using pipette method (Day 1965). This method involves two steps: (a) dispersion; and (b) fractionation. The texture of the soil was determined from the relative proportions of sand, silt and clay that it contained, using the soil textural triangle (Toogood 1958). All the spatial and non-spatial information generated, as described above, was integrated into a geospatial soil database for use in the SWAT model.

\section{Results and discussion}

The research involved a host of multidisciplinary methods and required the integrated use of satellite data, field observations, simulation models and geospatial analysis to accomplish the research objective. The myriad of results obtained on geomorphology, topography, hydrology, land use/land cover and simulation modelling, are therefore analysed and discussed chronologically under the following headings.

\subsection{Morphometric analysis}

The values of various morphometric parameters estimated using the methods described in table 1 are shown in table 4 . The hydrological significance of these parameters is discussed here.

\subsubsection{Stream order $(U)$}

The primary step in drainage-basin analysis is to designate stream orders (Horton 1945). As per the Strahler (1964) ordering scheme, all the five watersheds are 4 th-order streams. Figure 3 shows the stream orders of the five watersheds. Higher stream order is associated with greater discharge and higher velocity of the stream flow.

\subsubsection{Stream number $\left(N_{u}\right)$}

The count of stream channels in its order is known as stream number (Horton 1945). Results as shown in table 4 indicate that W1 has 66, 
Hydrological response in the Upper Indus Basin

\begin{tabular}{|c|c|c|c|c|c|}
\hline 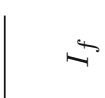 & $\begin{array}{l}\overrightarrow{0} \\
\stackrel{\infty}{\rightarrow}\end{array}$ & $\begin{array}{l}\stackrel{20}{\rightarrow} \\
\stackrel{\infty}{9} \\
\rightarrow\end{array}$ & $\stackrel{\overrightarrow{0}}{\stackrel{\leftrightarrow}{\sim}}$ & $\begin{array}{l}\stackrel{\mathscr{0}}{0} \\
\stackrel{\leftrightarrow}{\rightarrow}\end{array}$ & $\begin{array}{l}\infty \\
\infty \\
\infty \\
\infty\end{array}$ \\
\hline Eิ & 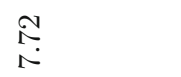 & 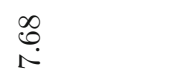 & $\underset{20}{\stackrel{9}{10}}$ & 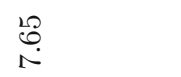 & $\underset{\stackrel{\leftrightarrow}{+}}{\stackrel{\leftrightarrow}{+}}$ \\
\hline-9 & $\stackrel{\sim}{\breve{0}}$ & $\stackrel{\infty}{\leftrightarrows}$ & $\stackrel{9}{\leftrightarrows}$ & $\stackrel{\infty}{\leftrightarrows}$ & $\exists$ \\
\hline$\approx$ & 帒 & $\stackrel{0}{0}$ & 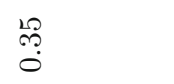 & $\stackrel{\sharp}{\sharp}$ & $\stackrel{N}{\infty}$ \\
\hline 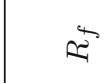 & $\underset{0}{F}$ & $\underset{0}{\exists}$ & $\overrightarrow{0}$ & $\underset{0}{\exists}$ & $\stackrel{\substack{N \\
0}}{0}$ \\
\hline$\sim^{2}$ & $\stackrel{0}{R}$ & $\begin{array}{l}10 \\
0 \\
0\end{array}$ & 당 & ชै & $\begin{array}{l}\infty \\
\infty \\
0\end{array}$ \\
\hline$E^{\infty}$ & 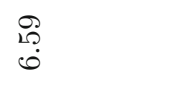 & $\begin{array}{l}\text { î. } \\
\text { i⿱ } \\
0\end{array}$ & $\stackrel{r}{+}$ & $\underset{20}{5}$ & $\begin{array}{l}\stackrel{1}{5} \\
\stackrel{9}{二}\end{array}$ \\
\hline$\theta^{\sigma}$ & $\underset{\dot{\infty}}{\overrightarrow{0}}$ & $\begin{array}{l}\infty \\
\infty \\
i\end{array}$ & 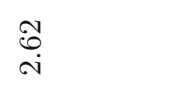 & $\underset{i}{\stackrel{N}{i}}$ & $\stackrel{10}{+i}$ \\
\hline है & $\stackrel{\sim}{\stackrel{\sim}{\rightleftarrows}}$ & $\stackrel{\leftrightarrow}{\stackrel{\rightarrow}{+}}$ & $\underset{H}{\stackrel{H}{s}}$ & $\stackrel{\sim}{\stackrel{\sim}{+}}$ & $\begin{array}{l}\mathscr{D} \\
\infty \\
10\end{array}$ \\
\hline $\overrightarrow{2}$ & $\stackrel{10}{L \infty}+\infty$ & 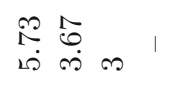 & 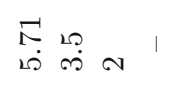 & 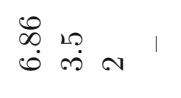 & $\stackrel{\hat{0}}{+}+\sigma^{\prime}$ \\
\hline$\vec{\Psi}$ & 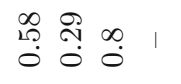 & 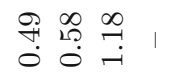 & 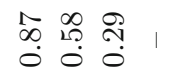 & 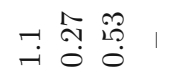 & 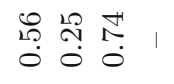 \\
\hline 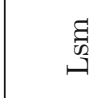 & 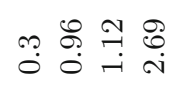 & 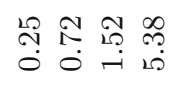 & ن. & 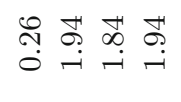 & 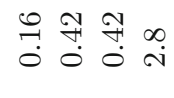 \\
\hline 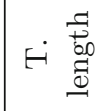 & 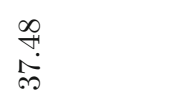 & $\begin{array}{l}\infty \\
\infty \\
\dot{\infty}\end{array}$ & 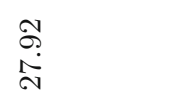 & 皇 & $\begin{array}{l}\vec{\infty} \\
\infty \\
\infty \\
+\end{array}$ \\
\hline ت & 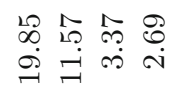 & 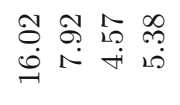 & 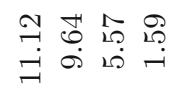 & 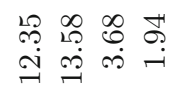 & 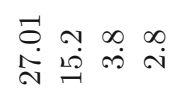 \\
\hline 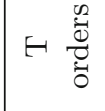 & $\stackrel{\infty}{\infty}$ & $\stackrel{\infty}{1}$ & 용 & $\stackrel{\infty}{\infty}$ & $\underset{\sim}{N}$ \\
\hline 苔总 & $\ddot{\theta} \cong r-$ & $\Re=\infty-1$ & of $\sim \sim-$ & $\stackrel{\infty}{\infty} \wedge \sim \neg$ & $\underbrace{\infty}_{0} \quad \infty$ \\
\hline $\overrightarrow{i s ~ o ~}$ & $\neg N \infty \neg$ & $\neg N \infty \neg$ & $\neg \sim \infty r$ & $\neg N \infty r$ & $\neg \sim \infty r$ \\
\hline 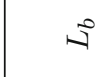 & 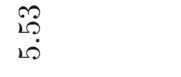 & $\underset{10}{F}$ & $\stackrel{\rho}{\rightarrow}$ & $\vec{p}$ & $\begin{array}{l}\vec{\sigma} \\
\dot{m}\end{array}$ \\
\hline 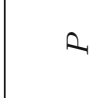 & $\begin{array}{l}\hat{1} \\
\hat{L} \\
0 \\
0\end{array}$ & $\underset{\sim}{\stackrel{\&}{:}}$ & $\stackrel{\stackrel{9}{+}}{\stackrel{\leftrightarrow}{\rightarrow}}$ & $\underset{\substack{20 \\
\stackrel{0}{-1}}}{\stackrel{1}{-1}}$ & 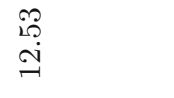 \\
\hline 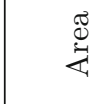 & $\begin{array}{l}\underset{H}{H} \\
\stackrel{I}{I}\end{array}$ & 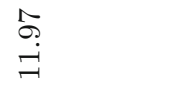 & $\begin{array}{l}\overrightarrow{0} \\
\stackrel{0}{0}\end{array}$ & 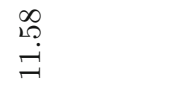 & $\begin{array}{l}\vec{\infty} \\
\stackrel{0}{0}\end{array}$ \\
\hline$\dot{n}$ & $F$ & 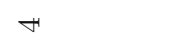 & 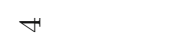 & 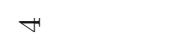 & 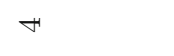 \\
\hline हี & $\overline{3}$ & $\stackrel{N}{3}$ & $\ddot{3}$ & $\overrightarrow{3}$ & $\stackrel{10}{3}$ \\
\hline
\end{tabular}



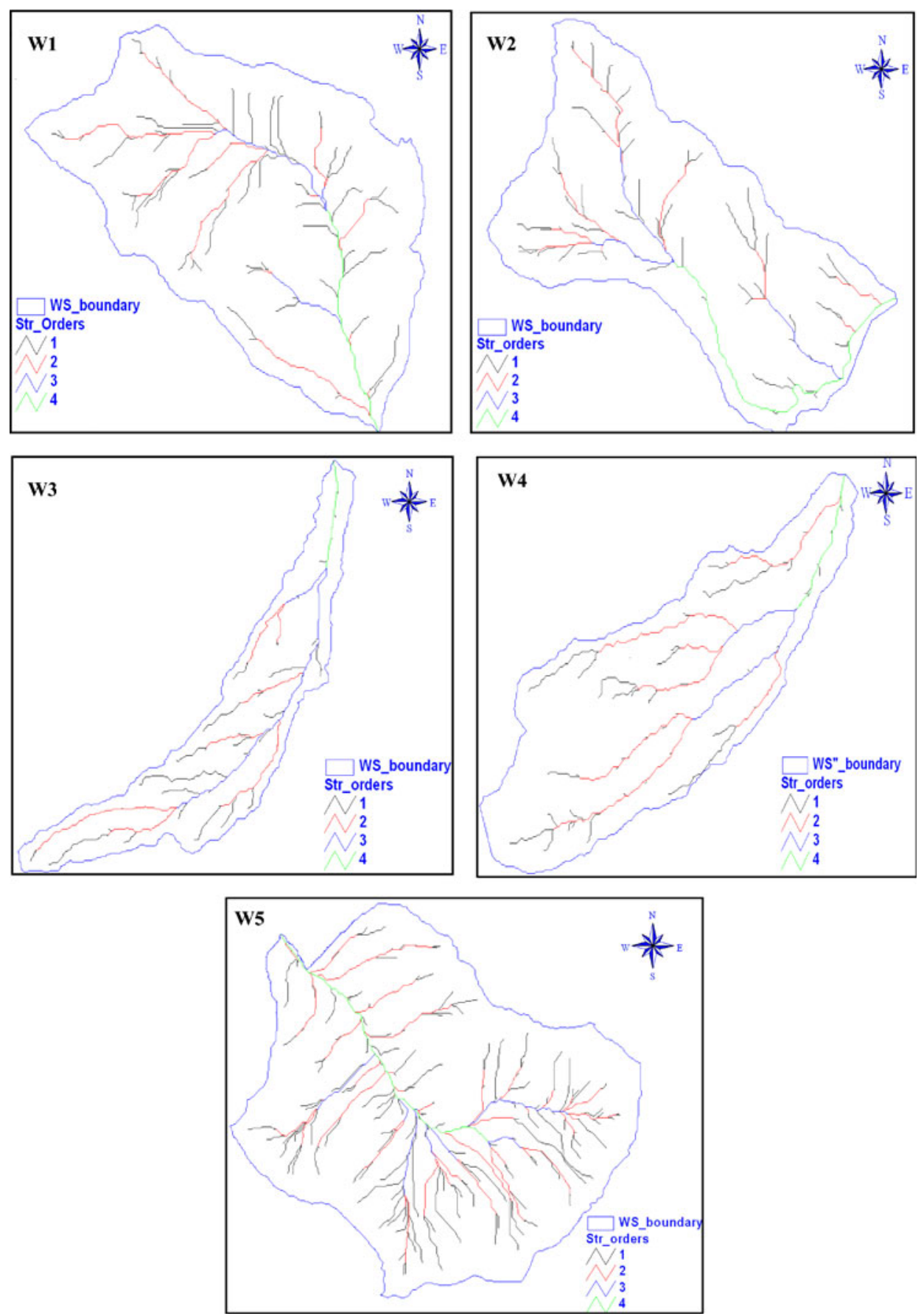

Figure 3. Drainage pattern and stream orders of the five watersheds.

12, 3 and 1 stream segments in 1st, 2nd, 3rd and 4 th orders, respectively; W2 has 36, 11, 3 and 1 in 1 st, 2 nd, 3rd and 4th orders, respectively; W3 has 40, 7, 2 and 1 in 1st, 2nd, 3rd and 4th orders, respectively; W4 has 48, 7, 2 and 1 in 1st, 2nd, 3rd and 4th orders, respectively and the W5 has 168, 36, 9 and 1 in 1st, 2nd, 3rd and 4th orders, respectively. The number of the stream segments decreases as the order increases. A higher stream number indicates lesser permeability and infiltration. Stream number is directly proportional to size of the contributing watershed and to channel dimensions. The maximum frequency in case of first order is unambiguous in all cases. Figure 4 shows the linear relationship between the number of streams and the stream orders in all the five watersheds. It means that the number of streams usually decreases in geometric progression as the stream order increases. The variations in rock structures of watersheds are responsible for inequalities in stream frequencies of each order. 

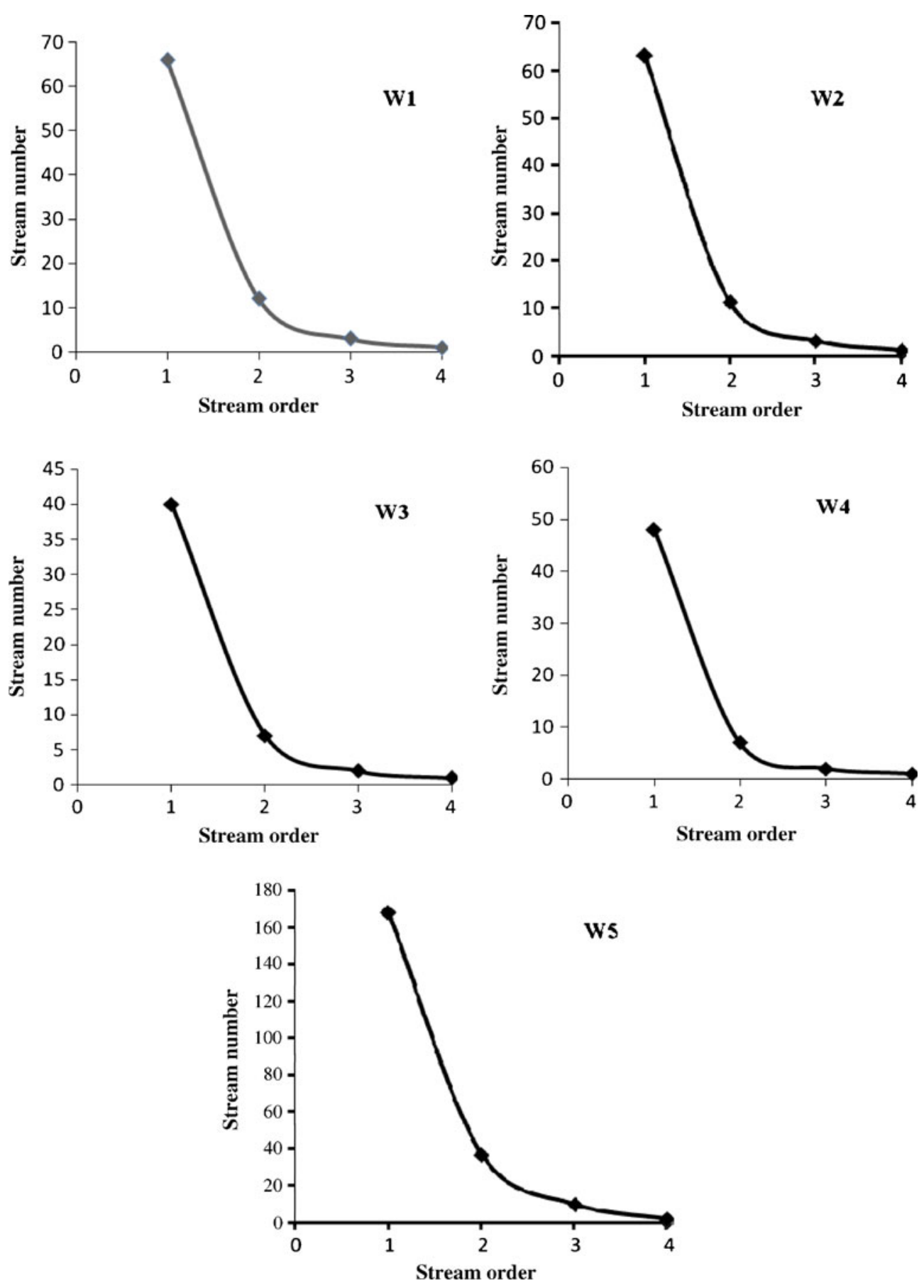

Figure 4. Stream order-stream number relation of the five watersheds.

\subsubsection{Stream length $\left(L_{u}\right)$}

Results show that the total length of stream segments is maximum in case of first-order streams. It decreases as order increases in case of W1, W3 and W5 as shown in figure 5. W2 and W4 do not shows geometric relationship and show variation from order to order as indicated in figure 5. This discrepancy is due to variations in relief and lithology over which these stream segments occur.

\subsubsection{Drainage density $\left(D_{d}\right)$}

The drainage density of W1, W2, W3, W4 and W5 are $3.01,2.83,2.62,2.72$ and 4.50 , respectively as shown in table 4 . The higher drainage density of W1 $\left(3.01 \mathrm{~km} / \mathrm{km}^{2}\right), \mathrm{W} 2\left(2.83 \mathrm{~km} / \mathrm{km}^{2}\right)$ and W5 $\left(4.5 \mathrm{~km} / \mathrm{km}^{2}\right)$ indicates that the regions under these watersheds are composed of impermeable subsurface material, sparse vegetation and mountainous relief. The lower drainage density of 

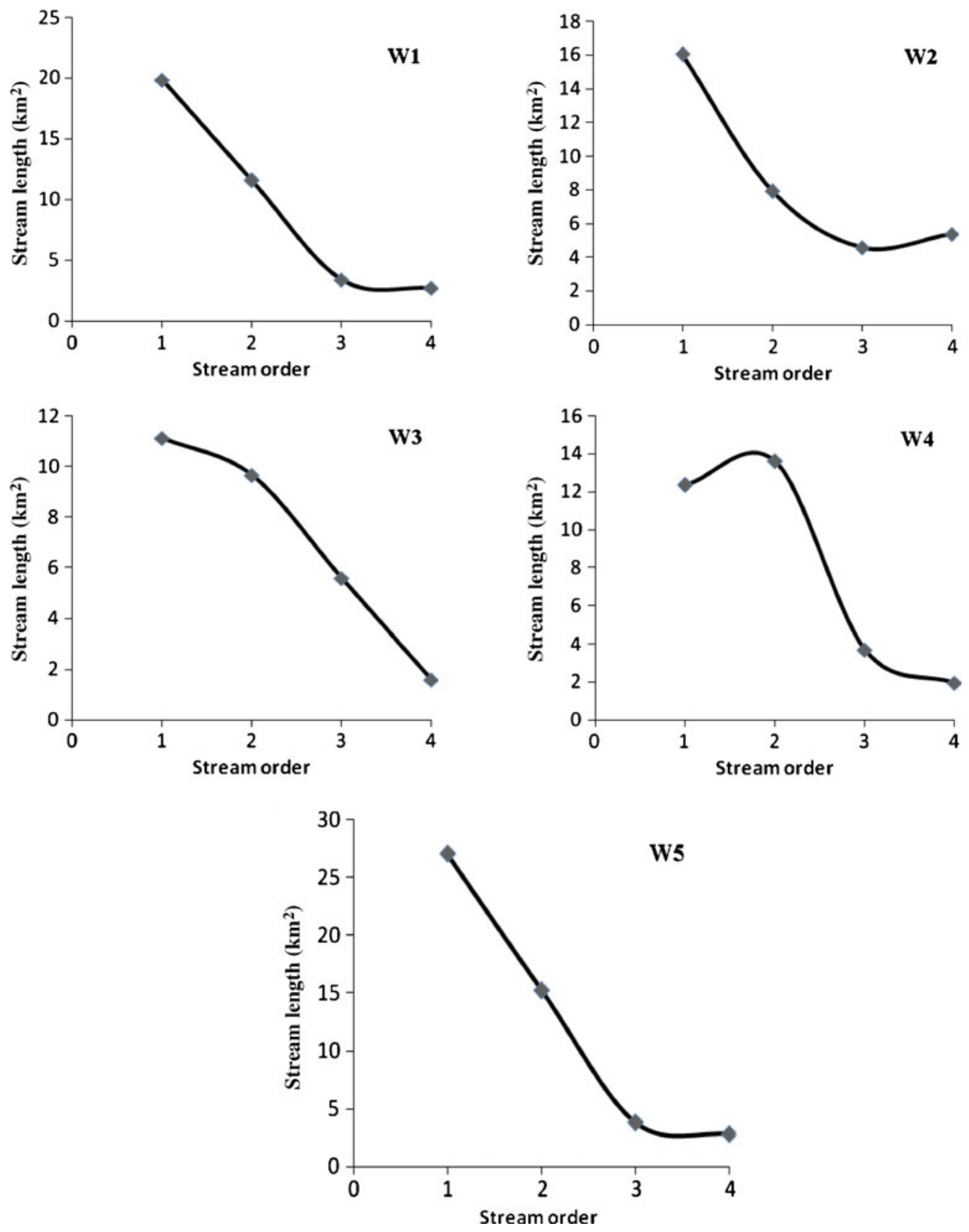

Figure 5. Stream order-stream length relation of the five watersheds.

$\mathrm{W} 3\left(2.62 \mathrm{~km} / \mathrm{km}^{2}\right)$ and $\mathrm{W} 4\left(2.72 \mathrm{~km} / \mathrm{km}^{2}\right)$ reveals that these watersheds are composed of permeable subsurface material, good vegetation cover and low relief as compared to other three watersheds, which results in more infiltration capacity and can be good sites for ground recharge sites. In general, the hydrology of watershed changes significantly in response to the changes in the drainage density (Yildiz 2004). A high drainage density reflects a highly dissected drainage basin with a relatively rapid hydrological response to rainfall events, while a low drainage density means a poorly drained basin with a slow hydrologic response (Melton 1957). Overall drainage density results indicate that W1, W2 and W5 contribute more surface runoff to the streams than W3 and W4. Carlston (1963) observed that there is a very close relationship between drainage density and mean annual

Table 5. Topographic parameters of the five watersheds.

\begin{tabular}{lccc}
\hline Watershed & $\begin{array}{c}\text { Minimum } \\
\text { elevation } \\
\text { (metres) }\end{array}$ & $\begin{array}{c}\text { Maximum } \\
\text { elevation } \\
\text { (metres) }\end{array}$ & $\begin{array}{c}\text { Average } \\
\text { slope } \\
\text { (degrees) }\end{array}$ \\
\hline W1 & 2881 & 4680 & 26.39 \\
W2 & 2931 & 4560 & 26.39 \\
W3 & 2100 & 2700 & 11.17 \\
W4 & 2108 & 2700 & 15.83 \\
W5 & 3480 & 4367 & 27.00 \\
\hline
\end{tabular}


flood. Therefore, W5 having highest drainage density followed by W1 and W2 are more prone to flooding than the other two watersheds.

\subsubsection{Stream frequency $\left(F_{s}\right)$}

The stream frequencies of $\mathrm{W} 1, \mathrm{~W} 2, \mathrm{~W} 3, \mathrm{~W} 4$ and W5 are $6.59,6.52,4.70,5.01$, and $19.74 \mathrm{~km}^{-2}$, respectively (table 4). Stream frequency is related to permeability, infiltration capacity and relief of watersheds (Montgomery and Dietrich 1989, 1992). W5 shows very high stream frequency $\left(19.74 \mathrm{~km}^{-2}\right)$, followed by W1 $\left(6.59 \mathrm{~km}^{-2}\right)$ and W2 $\left(6.52 \mathrm{~km}^{-2}\right)$. These values indicate that W5 has rocky terrain and very low infiltration capacity among all of the five watersheds. Further, it is noted that stream frequency decreases as the stream number increases. Stream frequencies of W3 $\left(4.70 \mathrm{~km}^{-2}\right)$ and $\mathrm{W} 4\left(5.01 \mathrm{~km}^{-2}\right)$ reveal that these watersheds are covered by vegetation and have very
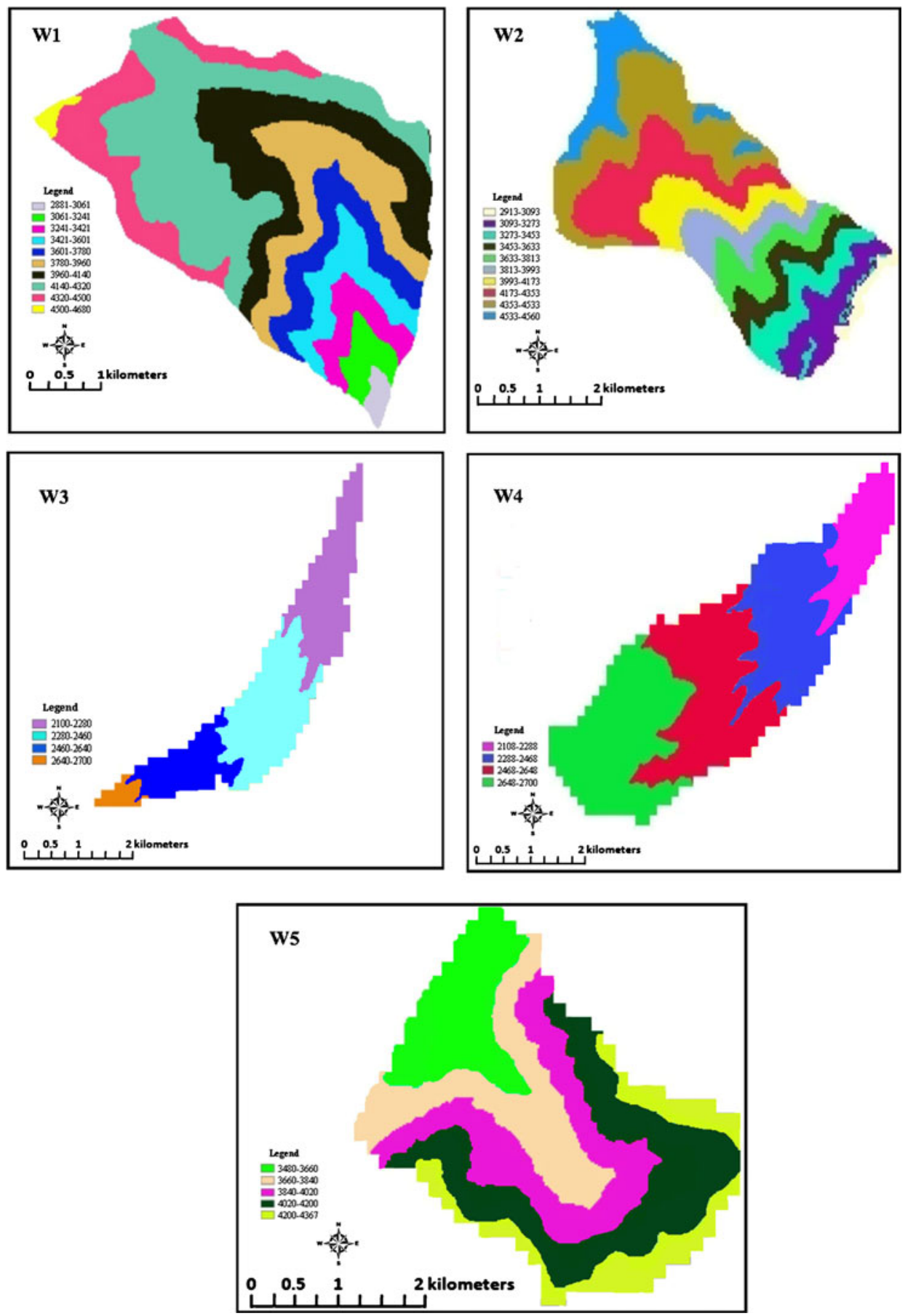

Figure 6. Elevation maps of the five watersheds. 
good infiltration capacity. Overall, the results of stream frequency reflect early peak discharge in case of W1, W2 and W5 that may result in flashfloods while the discharge from W3 and W4 would take time to peak because of low runoff rates.

\subsubsection{Bifurcation ratio $\left(R_{b}\right)$}

The mean bifurcation ratios of $\mathrm{W} 1, \mathrm{~W} 2, \mathrm{~W} 3$, $\mathrm{W} 4$, and $\mathrm{W} 5$ are $4.17,4.13,3.74,4.12$ and 5.89, respectively. The bifurcation ratio will not be precisely the same from one order to the next, because of possibility of variations in watershed geometry and lithology, but tends to be a constant throughout the series. The high bifurcation ratio indicates early hydrograph peak with a potential for flash flooding during the storm events (Rakesh et al 2000). Therefore, higher bifurcation ratio for W5 watershed indicates its vulnerability to flooding.

\subsubsection{Length of overland flow $\left(L_{g}\right)$}

Length of overland flow is one of the most important independent variables affecting both hydrologic and physiographic development of drainage basins (Horton 1932). From table 4, it can be seen
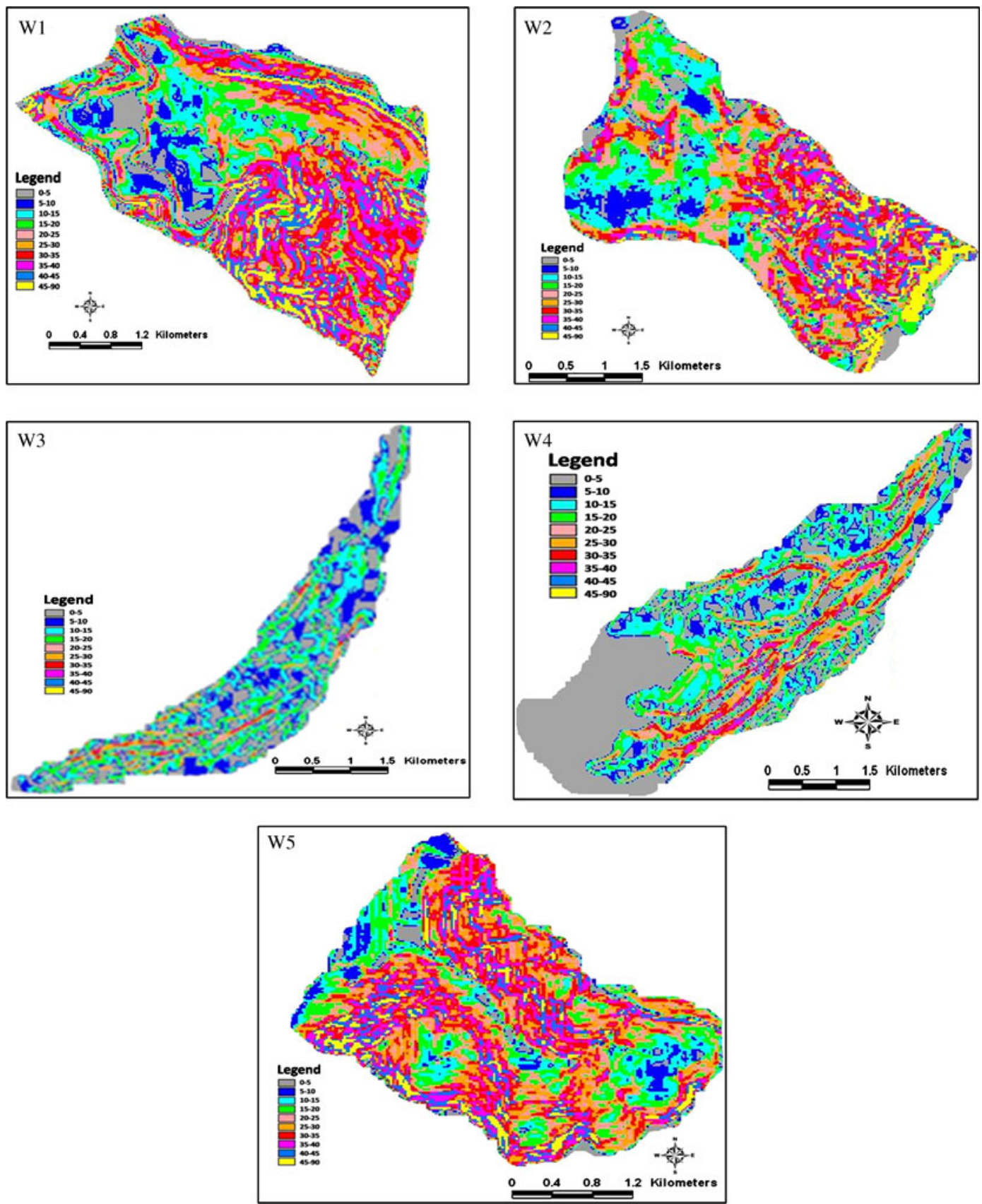

Figure 7. Slope map of the five watersheds. 
that lengths of overland flow of W1, W2, W3, W4 and W5 watersheds are $0.17,0.18,0.19,0.18$ and 0.11 , respectively. The values of length of overland flow of watersheds, W1 (0.17), W2 (0.18), W3 (0.19) and W4 (0.18) indicate gentler slopes and longer flow paths than W5 (0.11). The values also indicate that runoff will take very less time to reach outlet in case of W5 followed by W1, W2, W4 and W3, respectively. Thus, W5 shall be more vulnerable to the flash flooding compared to the other watersheds.

\subsubsection{Form factor $\left(R_{f}\right)$}

The form factor values of $\mathrm{W} 1, \mathrm{~W} 2, \mathrm{~W} 3, \mathrm{~W} 4$ and W5 are $0.41,0.41,0.61,0.41$ and 0.72 , respectively as shown in table 4 . It indicates that W5 is circular with higher value of 0.72 whereas remaining four watersheds are elongated. Watershed morphology has profound impact on watershed hydrology (Tucker and Bras 1998). This again reaffirms that W5 will have quick, though lower, hydrograph peak compared to the other watersheds.

\subsubsection{Elongation ratio $\left(R_{e}\right)$}

Table 4 shows that the elongation ratio of the five watersheds varies from 0.62 to 0.88 . W5 has highest values of 0.88 followed by W1 (0.79), W2 (0.75), W3 (0.71) and W4 (0.62). Results of elongation ratio indicate that W5 is circular, W3 is oval and remaining (W1, W2 and W4) watersheds are less-elongated. The impact of varied watershed morphology on the hydrological response shall be similar as that of the form factor discussed here (Strahler 1964).

\subsubsection{Ellipticity index $\left(E_{i}\right)$}

$\mathrm{W} 1, \mathrm{~W} 2, \mathrm{~W} 3, \mathrm{~W} 4$ and $\mathrm{W} 5$ have elipticity indices of $7.17,7.68,5.19,7.65$ and 4.49 , respectively (table 4). The elipticity index provides similar insights about the relationship between morphometry and hydrology as other shape-related parameters. Lower values indicate that the runoff from the catchment drains quickly into the channels and thereby, depending upon the total quantum of the precipitation, the channels may swell or even overflow resulting in flooding downstream areas.

\subsubsection{Circulatory ratio $\left(R_{c}\right)$}

The circulatory ratios of $\mathrm{W} 1, \mathrm{~W} 2, \mathrm{~W} 3, \mathrm{~W} 4$ and W5 are $0.57,0.46,0.35,0.44$ and 0.87 , respectively (table 4). Circulatory ratio results from the five watersheds show that W1 (0.57) and W5 (0.87) are more or less circular and are characterized by high to moderate relief. The remaining watersheds (W2, W3 and W4) indicate that they are elongated and are characterized by moderate to low relief.

All the above shape-related parameters significantly influence the hydrological response of the watersheds as basin-shaped and the arrangement of stream segments combine to influence the size and shape of flood peaks (Ward and Robinson 2000). As such, W5 has high flood peaks followed by W1 and W2 as compared to W3 and W4.

\subsubsection{Infiltration number (If)}

Infiltration number plays a significant role in observing the infiltration character of basin. It is inversely proportional to the infiltration capacity of the basin. The infiltration numbers of W1, W2, W3, W4 and W5 are 19.94, 18.45, 12.34, 13.65 and 88.86, respectively (table 4 ). The results reveal that W5 has very low infiltration capacity, W1 and W2 have low infiltration capacity and W3 and W4 have high infiltration capacity. It indicates that runoff will be very high in case of W5 followed by W1 and

Table 6. Distribution of slope classes in the five watersheds.

\begin{tabular}{lccccr}
\hline \multirow{2}{*}{$\begin{array}{l}\text { Slope } \\
\text { classes }\end{array}$} & \multicolumn{5}{c}{ Area $\left(\mathrm{km}^{2}\right)$} \\
\cline { 2 - 6 } W1 & $\mathrm{W} 2$ & $\mathrm{~W} 3$ & $\mathrm{~W} 4$ & W5 \\
\hline $5-5$ & 0.88 & 0.76 & 3.14 & 3.63 & 0.41 \\
$5-10$ & 0.97 & 0.88 & 2.57 & 1.46 & 0.56 \\
$10-15$ & 1.21 & 1.33 & 2.86 & 2.29 & 0.88 \\
$15-20$ & 1.35 & 1.46 & 1.14 & 1.60 & 1.15 \\
$20-25$ & 1.41 & 1.44 & 0.58 & 1.18 & 1.21 \\
$25-30$ & 1.42 & 1.62 & 0.22 & 0.62 & 1.44 \\
$30-35$ & 2.09 & 1.63 & 0.09 & 0.50 & 1.44 \\
$35-40$ & 1.39 & 1.30 & 0.03 & 0.24 & 1.22 \\
$40-45$ & 1.00 & 0.75 & 0.01 & 0.05 & 1.13 \\
$45-90$ & 0.72 & 0.80 & 0.00 & 0.01 & 1.40 \\
\hline
\end{tabular}


W2 during rain spells. It means that downstream areas of W5 shall be flooded very quickly followed by $\mathrm{W} 1$ and $\mathrm{W} 2$.

\subsection{Topographic analysis}

The topographic parameters of W1, W2, W3, W4 and W5 have been calculated using DEM
(Tarboton 1989). The minimum elevation of W1, $\mathrm{W} 2, \mathrm{~W} 3, \mathrm{~W} 4$ and $\mathrm{W} 5$ ranges between 2100 and $3480 \mathrm{~m}$ a.m.s.l, and the maximum elevation of $\mathrm{W} 1, \mathrm{~W} 2, \mathrm{~W} 3, \mathrm{~W} 4$ and $\mathrm{W} 5$ ranges between 2700 and $4680 \mathrm{~m}$ a.m.s.l, as shown in table 5 and figure 6 . The average slope of watersheds varies from $11.17^{\circ}$ to $27^{\circ}$. W5 has an average slope of $27^{\circ}$ followed by $\mathrm{W} 1$ and $\mathrm{W} 2\left(26.39^{\circ}\right)$, W3 $\left(11.17^{\circ}\right)$ and W4 $\left(15.83^{\circ}\right)$. Higher average slope for W1, W2
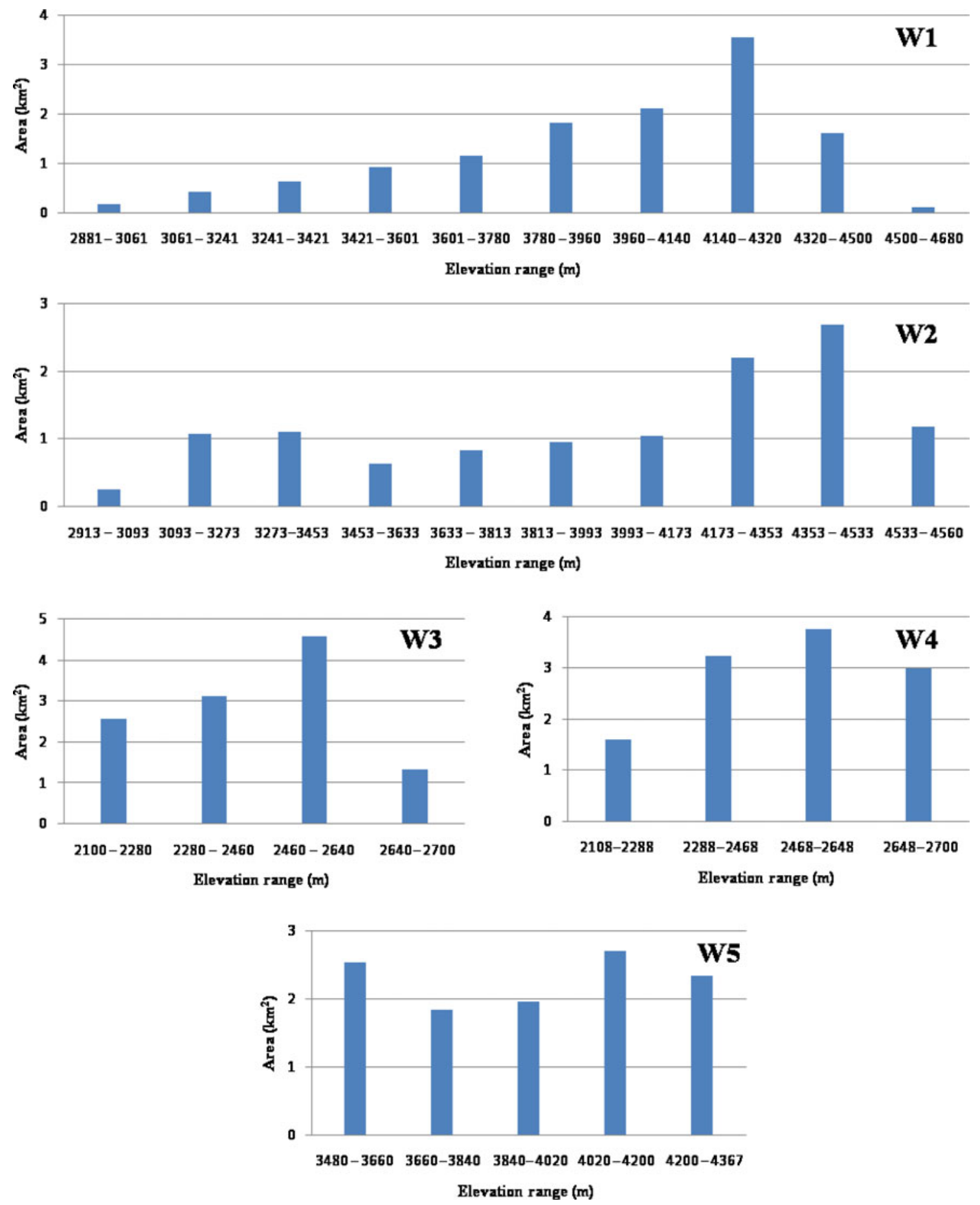

Figure 8. Area-elevation distribution in the five watersheds. 
and W5 is an indication of generating quick runoff during rains or storm events (Tucker and Bras 1998). The different slope categories of each watershed are shown in figure 7. Catchment morphology and hydrology are strongly influenced by hillslope processes (Tucker and Bras 1998). Slope/area relation analysis as shown in table 6 indicates that $\mathrm{W} 1$, W2 and W5 have large areas under high slopes compared to W3 and W4, which also reaffirms that these watersheds generate higher runoff during

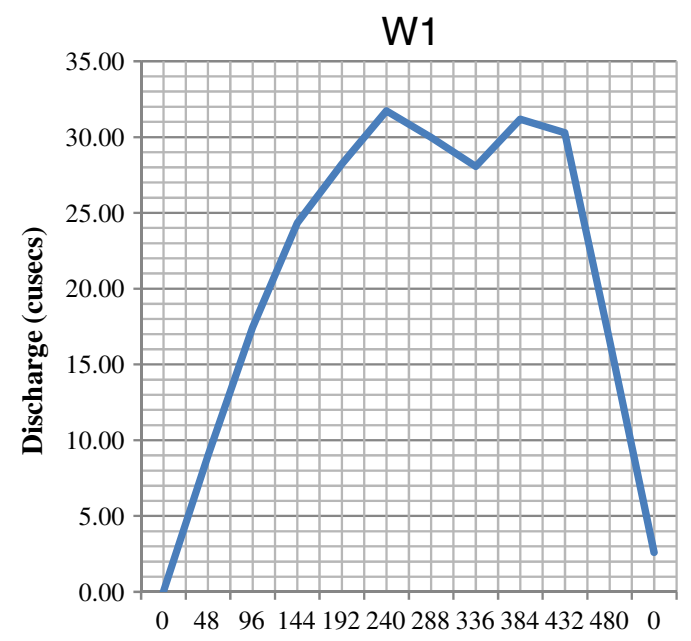

Time (minutes)

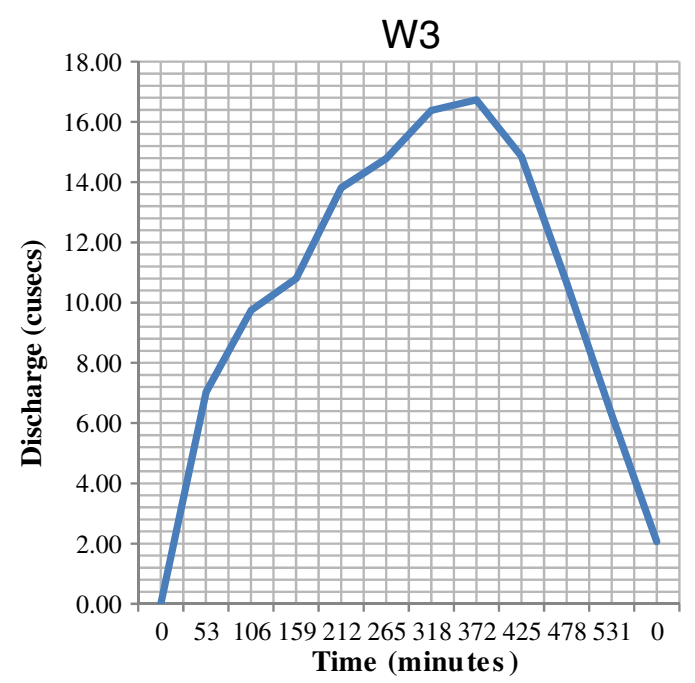

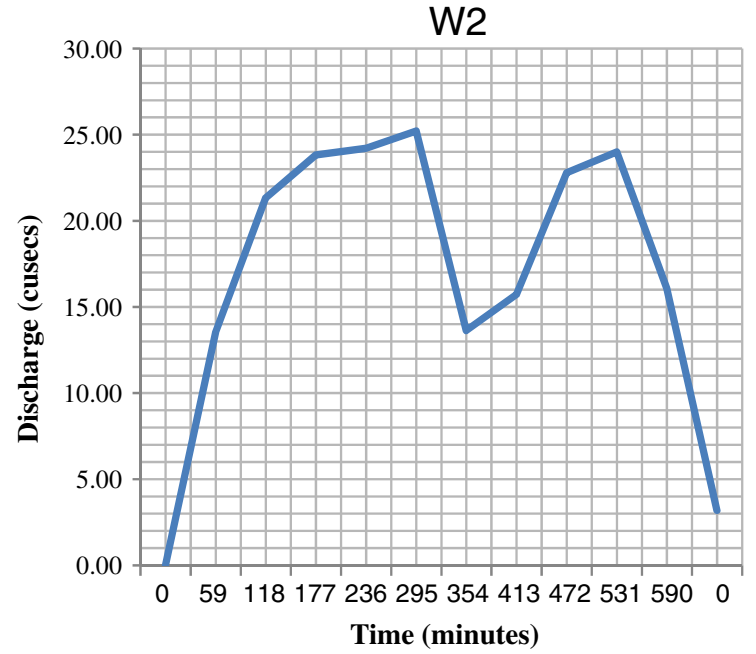

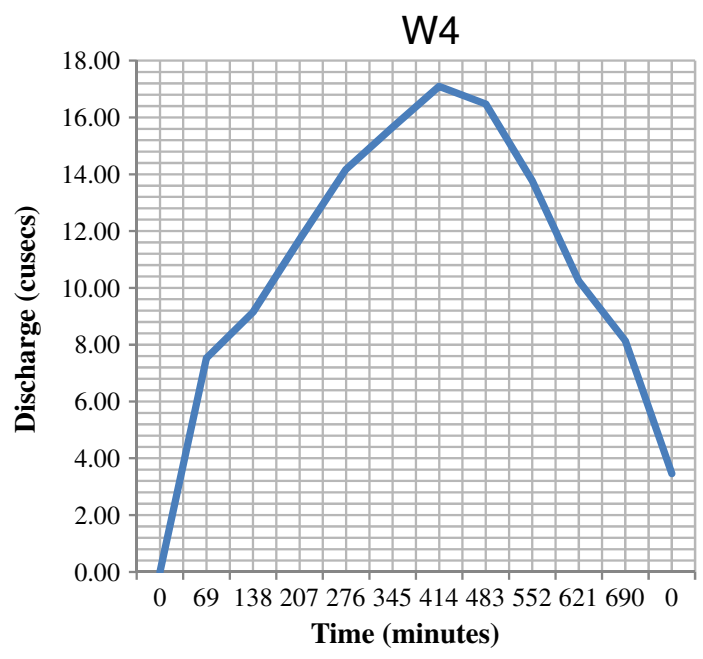

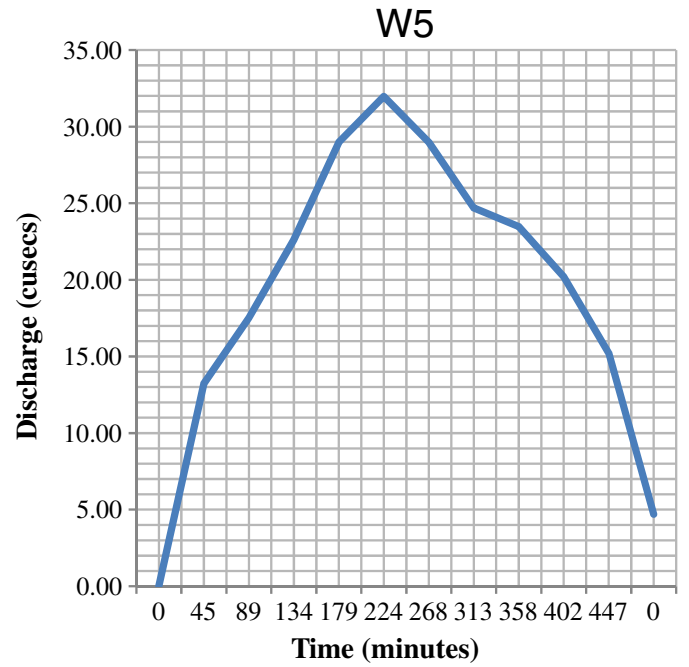

Figure 9. Instantaneous unit hydrographs results of the five ungauged watersheds. 
rainfall events. These watersheds are therefore highly prone to flooding than the other two watersheds. There is a significant relationship between the slope and the contributing area (Willgoose 1996). Area-elevation analysis for each of these watersheds, as shown in figure 8 indicates that W1 and W2 have smaller areas under higher elevations compared to W3, W4 and W5. This again indicates that quick runoff may be generated from these watersheds that may result in flooding over prolonged rainy spells.

\subsection{Synthetic unit hydrograph analysis}

Instantaneous unit hydrograph results of all five ungauged watersheds are shown graphically in figure 9 and tabulated in table 7 . The results indicate that W5 has high peak discharge of 31.98 cusecs and least time to peak of 224 minutes followed by W1 of peak discharge of 31.74 cusecs and time to peak of 240 minutes and W2 peak discharge of 25.22 cusecs and time to peak of 295 minutes. While W3 has a peak discharge of 16.74 cusecs and time to peak of 372 minutes followed by W4 which has a peak discharge of 17.09 cusecs and time to peak of 483 minutes. The results clearly reveal that W5 with highest discharge potential and lower time to hydrograph peak, is more prone to flooding as compared to other watersheds. Results also reaffirm that $\mathrm{W} 1$ is almost equally prone to large surges of water discharge and consequent flooding.

\subsection{Hydrological model simulations}

In order to simulate the hydrological response (runoff) from these five watersheds using SWAT, various input parameters related to hydrometeorology, land use/cover data, topography, soil, etc. were generated as already described. The analyses of these input parameters are discussed here.

\subsubsection{Hydrometeorological data analysis}

Hydrometeorological data were analysed to generate the spatial distribution of the necessary input

Table 7. Time-to-peak and peak discharges from the five watersheds.

\begin{tabular}{lcc}
\hline Watershed & $\begin{array}{c}\text { Time to peak } \\
\text { (minutes) }\end{array}$ & $\begin{array}{c}\text { Peak discharge } \\
\text { (cusecs) }\end{array}$ \\
\hline W1 & 240 & 31.74 \\
W2 & 295 & 25.22 \\
W3 & 372 & 16.74 \\
W4 & 483 & 17.09 \\
W5 & 224 & 31.98 \\
\hline
\end{tabular}

parameters for SWAT model. Spatial distribution of hydrometeorological data is required for the simulation of hydrological and meteorological response at the watersheds scale using distributed hydrological and climate models (Hamlet and Lettenmaier 1999). Estimation of the spatial distribution of these variables depends on the number and distribution of the observation stations. The spatial distribution of the average precipitation over a larger area including five watersheds is shown in figure $10(\mathrm{a}, \mathrm{b})$ for all the 12 months of the year. The figures indicate that average monthly rainfall increases towards the south-western areas of the catchment. They further reveal that the catchment receives highest rainfall in March (86-142 mm) and lowest in November (18-32 mm). Analysis of the average yearly rainfall of 20 years also shows an increasing trend towards the southwestern areas of the catchment. Southern areas receive $864-913 \mathrm{~mm}$ yearly average precipitation whereas north-western areas receive 423-472 $\mathrm{mm}$. The southern areas are receiving higher precipitation because of the higher altitude. Most of the precipitation is in the form of snow in these mountainous regions of the catchment. As seen from the figures, there is marked spatial variation in the distribution of the precipitation for all months of the year. Further, orographic influences on precipitation are quite discernible from the interpolated precipitation patterns.

The analysis of 20 years (1979-1999) of meteorological data, as shown in table 2, indicates that the average daily maximum temperature was observed to be highest in July $\left(29.59^{\circ} \mathrm{C}\right)$ and lowest in January $\left(4.56^{\circ} \mathrm{C}\right)$ and average daily minimum temperature was observed to be lowest in January $\left(-6.77^{\circ} \mathrm{C}\right)$ and highest in July $\left(17.28^{\circ} \mathrm{C}\right)$. The average daily precipitation was observed to be maximum in March (4.38 mm) and minimum in November $(0.59 \mathrm{~mm})$. The average daily solar radiation was observed to be maximum in June $\left(19.28 \mathrm{MJ} / \mathrm{m}^{2} /\right.$ day $)$ and minimum in January $\left(8.75 \mathrm{MJ} / \mathrm{m}^{2} /\right.$ day $)$. The average daily dew point temperature was observed to be maximum in August $\left(8.74^{\circ} \mathrm{C}\right)$ and minimum in January $\left(-7.51^{\circ} \mathrm{C}\right)$. The average daily wind speed was observed to be maximum in April $(3.4 \mathrm{~m} / \mathrm{s})$ and minimum in October $(1.74 \mathrm{~m} / \mathrm{s})$. These values of the hydrometeorological parameters observed in the area are typical for temperate Himalayan regions.

\subsubsection{Land use/land cover analysis}

The various land use and land cover classes delineated in the five watersheds include exposed rocks, shrubs, forests, pastures and barren lands as shown 

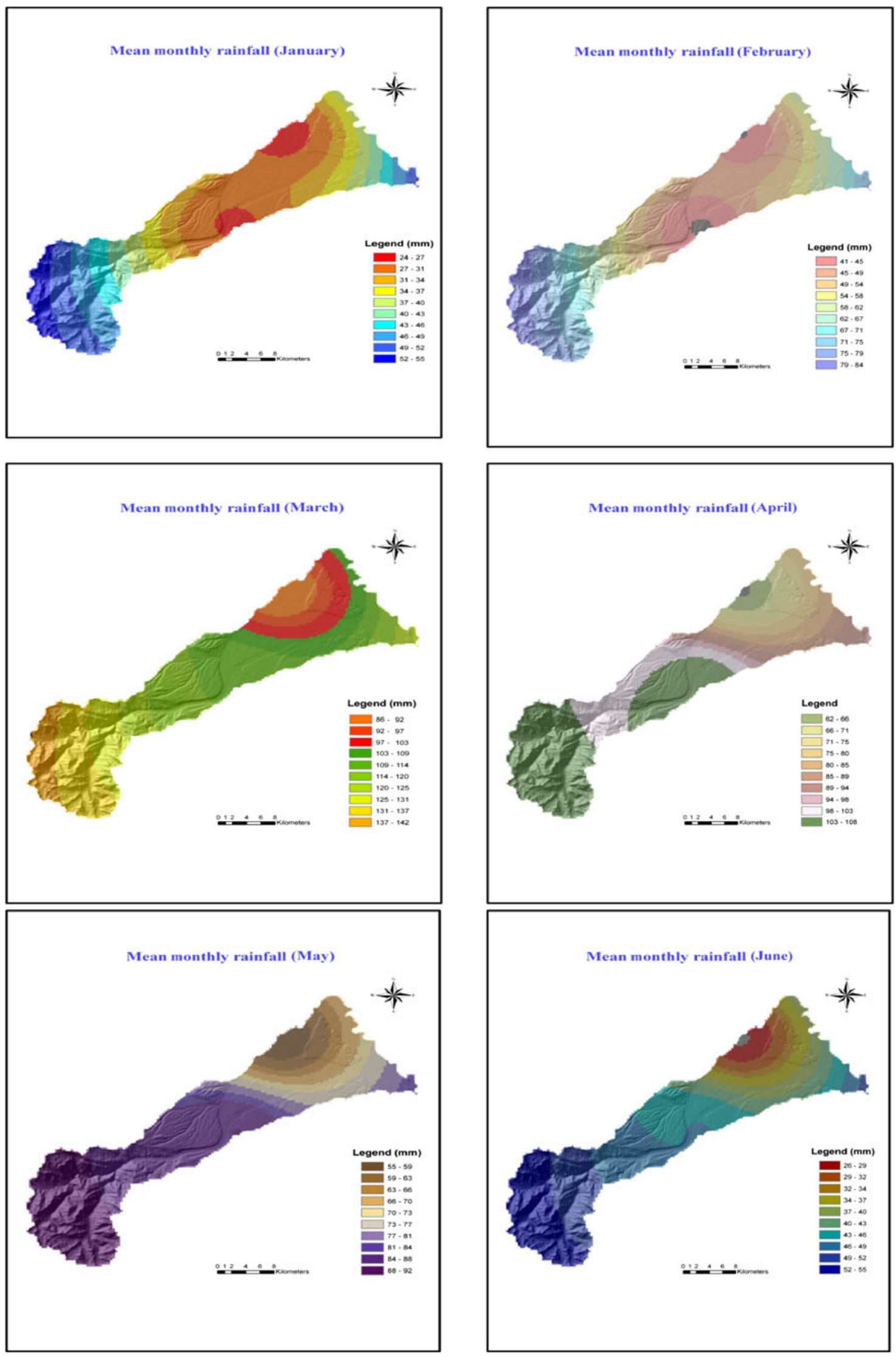

Figure 10. (a) Spatial distribution of average monthly rainfall of Rembiara catchment (January-June). 

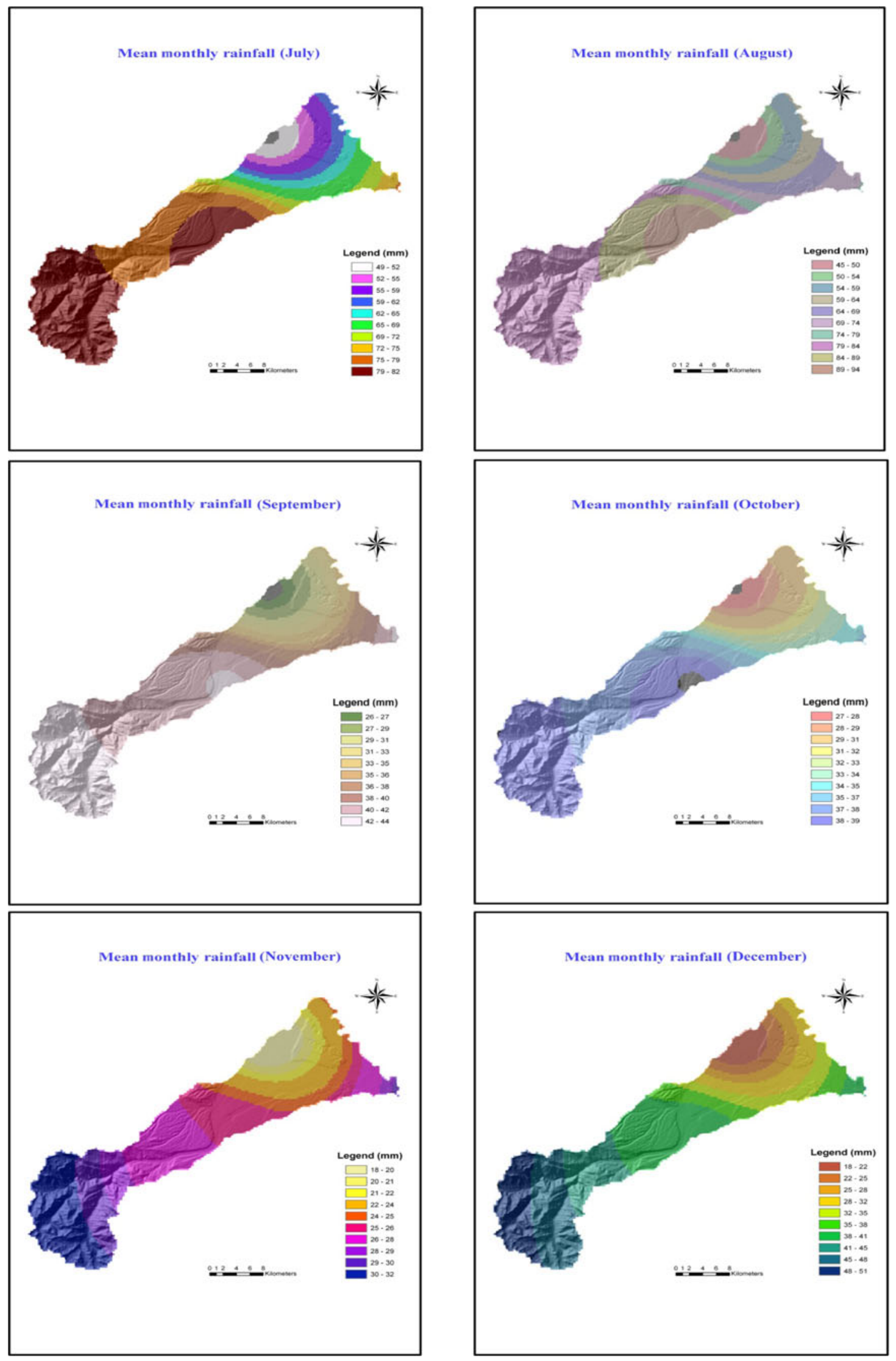

Figure 10. (b) Spatial distribution of average monthly rainfall of Rembiara catchment (July-December). 

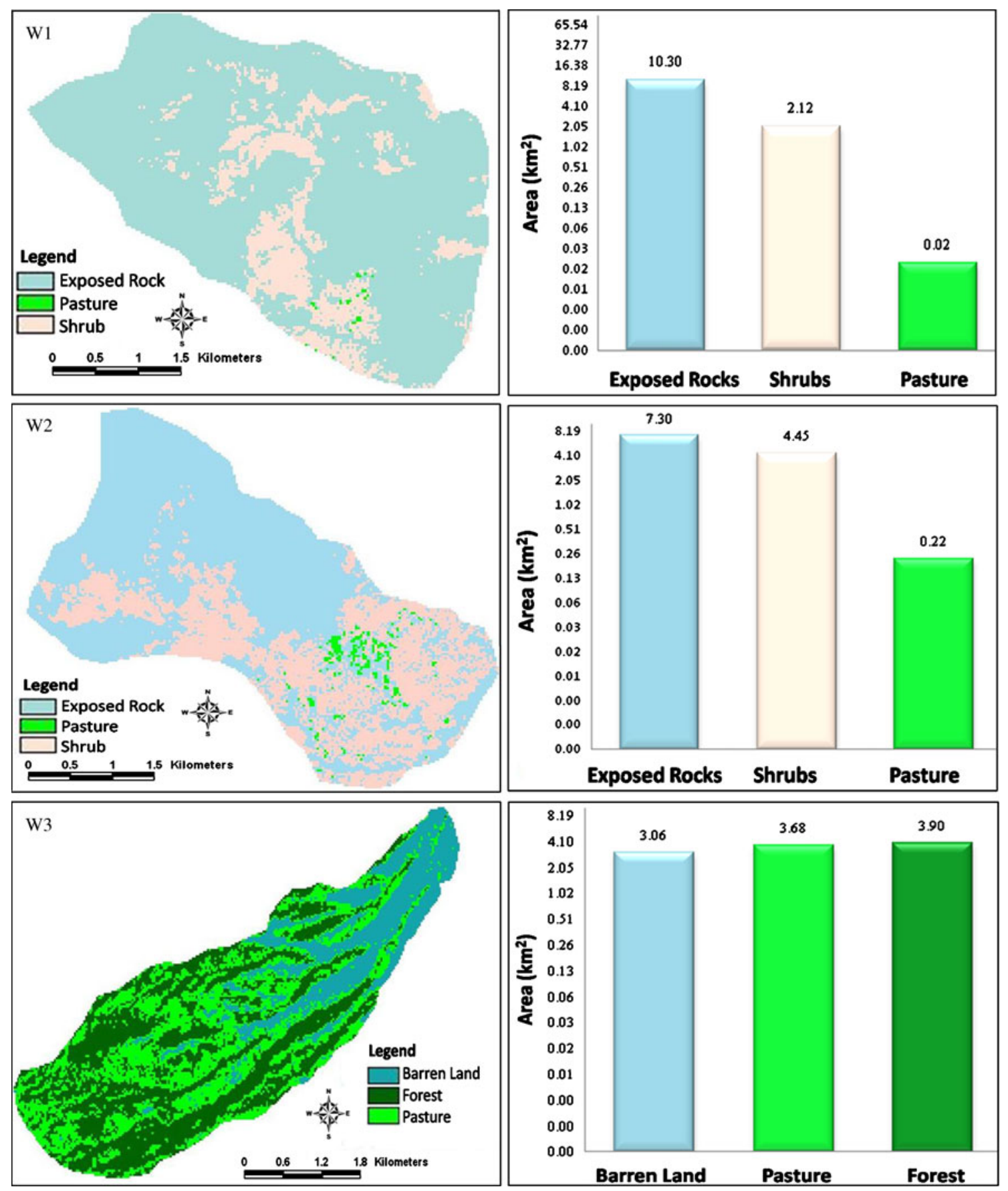

Figure 11. (a) Land use/land cover map and areal distribution of W1, W2 and W3.

in figure 11(a) for $\mathrm{W} 1, \mathrm{~W} 2$ and $\mathrm{W} 3$, and figure 11(b) for W4 and W5. The distribution of the land use land cover classes in each of the five watersheds is given in table 8 . W1 has $82.80 \%, 17.04 \%$ and $0.16 \%$ under exposed rocks, shrubs and pastures, respectively. W2 has $60.99 \%, 37.18 \%$ and $1.84 \%$ under exposed rocks, shrubs and pastures, respectively. W3 has $28.76 \%, 34.59 \%$ and $36.65 \%$ under barren lands, pastures and forests, respectively. W4 has $17.96 \%, 36.70 \%$ and $45.34 \%$ under barren lands, pastures and forests, respectively. W5 has
$61.07 \%, 25.0 \%, 10.17 \%$ and $3.23 \%$ under exposed rocks, shrubs, forests and pastures, respectively. These results show that $\mathrm{W} 1, \mathrm{~W} 2$, and $\mathrm{W} 5$ are mostly covered by exposed rocks while W3 and W4 have highest percentage of forest land. The type and distribution of land cover have profound impact on a number of hydrological processes (Matheussen et al 2000; Fohrer et al 2001; Quilbe et al 2008). Therefore, W1, W2 and W5 with lowest vegetation cover, shall generate more surface runoff compared to the other two watersheds. W5, in 

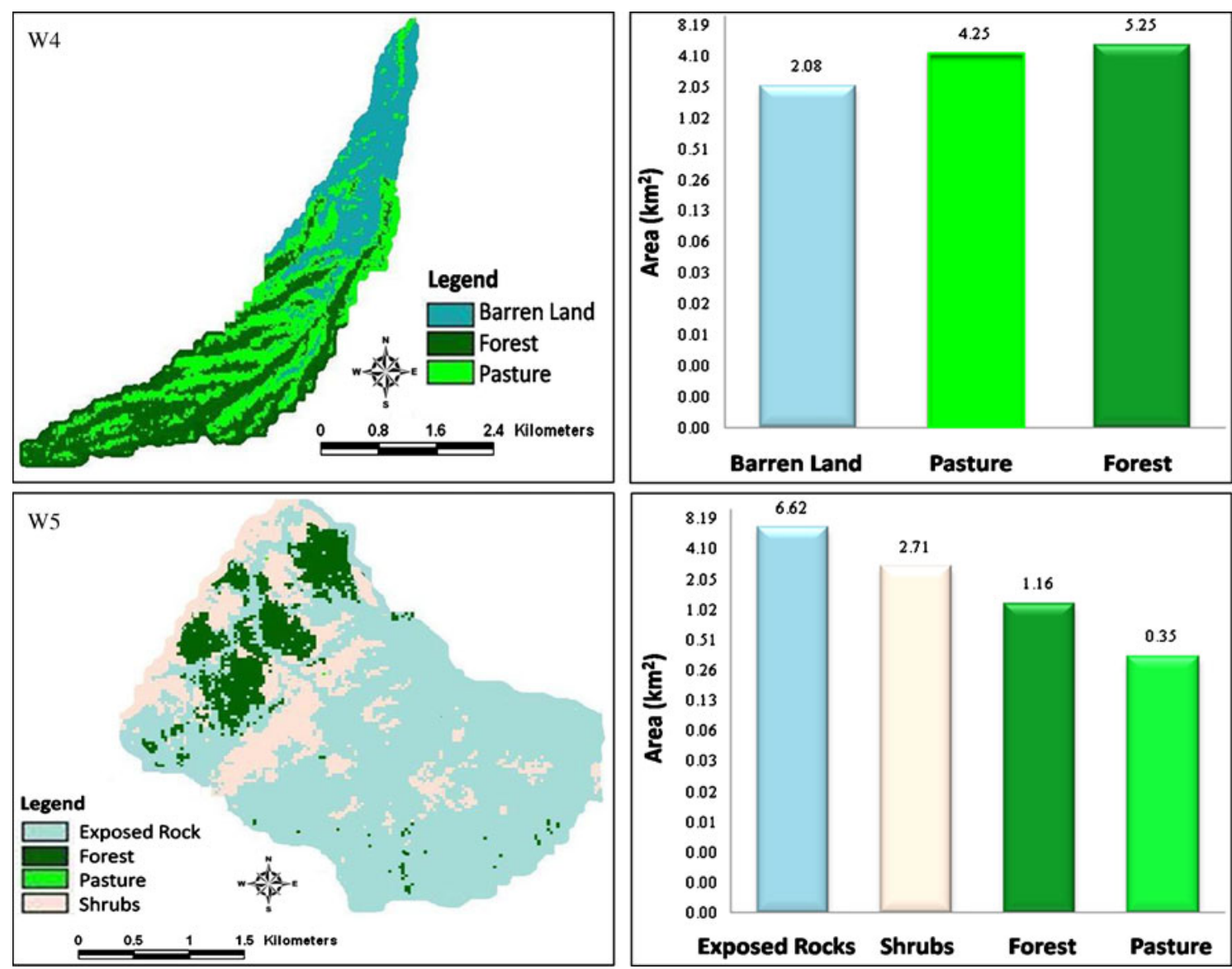

Figure 11. (b) Land use/land cover map and areal distribution of W4 and W5.

Table 8. Land use/land cover distribution in the five watersheds.

\begin{tabular}{|c|c|c|c|c|c|c|c|}
\hline Sl. no. & $\begin{array}{l}\text { Land cover/ } \\
\text { land use }\end{array}$ & $\begin{array}{c}\text { Area } \\
\left(\mathrm{km}^{2}\right)\end{array}$ & $\%$ Area & \multicolumn{4}{|c|}{$\begin{array}{l}\text { surface runoff, is prone to flooding during extreme } \\
\text { storm events. }\end{array}$} \\
\hline \multicolumn{8}{|c|}{ W1 Watershed } \\
\hline 01 & Exposed rocks & 10.30 & 82.80 & & & & \\
\hline 02 & Shrubs & 2.12 & 17.04 & \multicolumn{4}{|c|}{ Table 9. Soil type distributions in the five watersheds. } \\
\hline \multicolumn{2}{|r|}{ Pastures } & 0.02 & 0.16 & & & \multirow{2}{*}{$\begin{array}{c}\text { Area } \\
\left(\mathrm{km}^{2}\right)\end{array}$} & \multirow[b]{2}{*}{$\%$ Area } \\
\hline $\begin{array}{l}\text { W2 Wa } \\
01\end{array}$ & Exposed rocks & 7.30 & 60.99 & Sl. no. & Soil type & & \\
\hline 02 & Shrubs & 4.45 & 37.18 & \multicolumn{4}{|c|}{ W1 Watershed } \\
\hline 03 & Pastures & 0.22 & 1.84 & 01 & Rock outcrop & 7.18 & 57.72 \\
\hline \multicolumn{4}{|c|}{ W3 Watershed } & 02 & Sandy clay loam & 5.26 & 42.28 \\
\hline 01 & Barren land & 3.06 & 28.76 & \multicolumn{4}{|c|}{ W2 Watershed } \\
\hline 02 & Pastures & 3.68 & 34.59 & 01 & Rock outcrop & 6.39 & 53.39 \\
\hline 03 & Forest & 3.90 & 36.65 & 02 & Sandy clay loam & 5.58 & 46.61 \\
\hline \multicolumn{4}{|c|}{ W4 Watershed } & \multicolumn{4}{|c|}{ W3 Watershed } \\
\hline 01 & Barren land & 2.08 & 17.96 & 01 & Clay loam & 6.85 & 64.32 \\
\hline 02 & Pastures & 4.25 & 36.70 & 02 & Sandy clay loam & 3.79 & 35.68 \\
\hline 03 & Forest & 5.25 & 45.34 & \multicolumn{4}{|c|}{ W4 Watershed } \\
\hline \multicolumn{4}{|c|}{ W5 Watershed } & 01 & Clay loam & 8.19 & 70.72 \\
\hline 01 & Exposed rocks & 6.62 & 61.07 & 02 & Sandy clay loam & 3.39 & 29.28 \\
\hline 02 & Shrubs & 2.71 & 25.00 & \multicolumn{4}{|c|}{ W5 Watershed } \\
\hline 03 & Forest & 1.16 & 10.70 & 01 & Rock outcrop & 7.76 & 71.59 \\
\hline 04 & Pastures & 0.35 & 3.23 & 02 & Sandy clay loam & 3.08 & 28.41 \\
\hline
\end{tabular}

particular, with highest drainage density and other geomorphological factors conducive for increased surface runoff, is prone to flooding during extreme storm events. 


\subsubsection{Soil data analysis}

The area under each of the soil texture types is given in table 9. It is evident that W1, W2 and W5 are dominated by rocky outcrops covering $57.72 \%, 53.39 \%$ and $71.59 \%$, respectively. W3 and W4 are dominated by clay loam soils covering $64.32 \%$ and $70.72 \%$ of the total area, respectively. Sandy clay loam covers an area of $42.28 \%$, $46.61 \%, 35.68 \%, 29.28 \%$ and $28.41 \%$ of $\mathrm{W} 1$, W2,
W3, W4 and W5, respectively. Soil texture properties such as the percentage of sand, silt, clay and soil hydrological groups of the watersheds are presented in table 10. Soil types influence the hydraulic properties of the soils and that in turn affect a number of hydrological processes at the watershed scale including the lateral and horizontal movements of the subsurface water (Entekhabi et al 1999; Romshoo 2004). Therefore, watersheds with large areas under barren and rocky outcrops
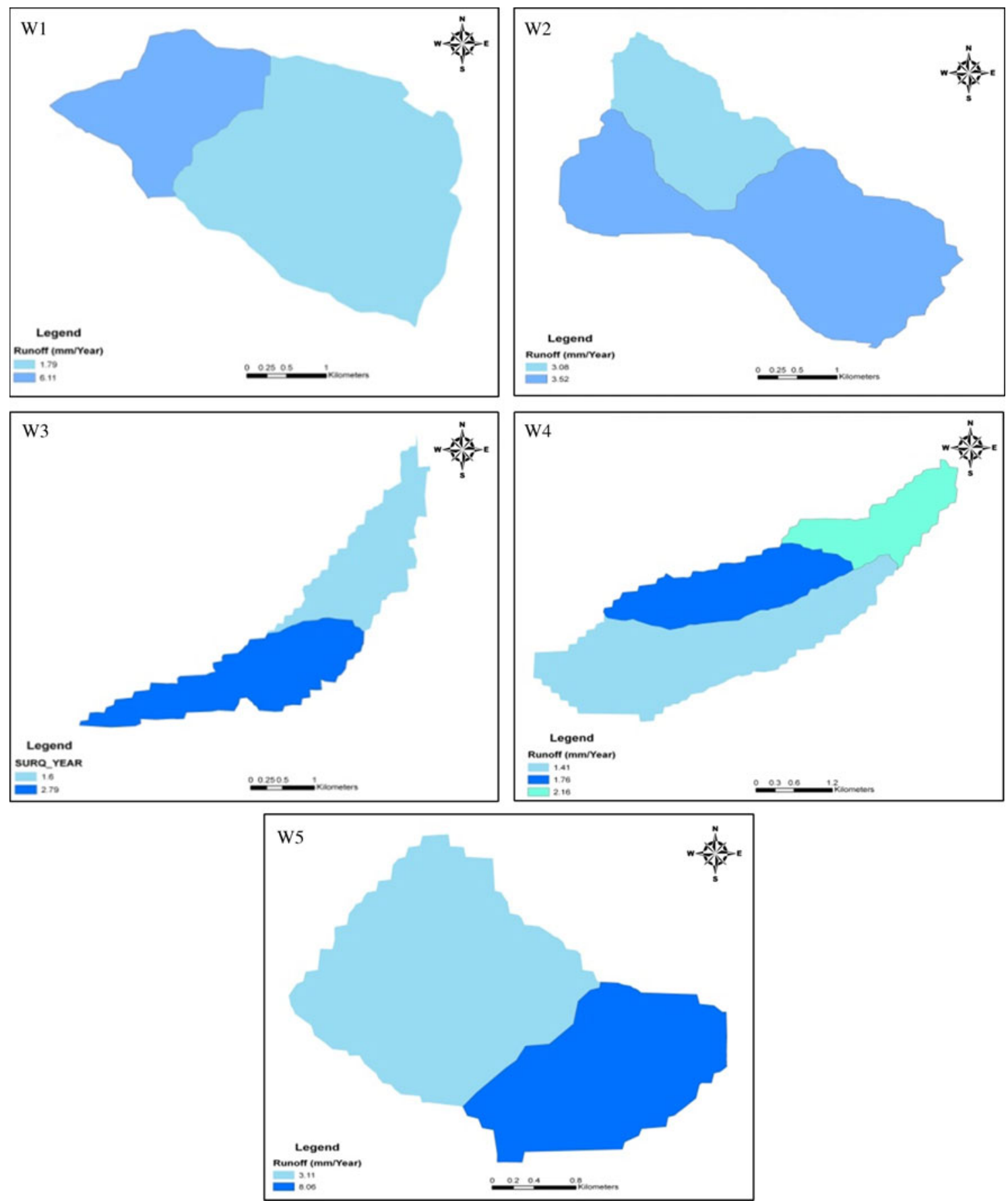

Figure 12. Simulated surface runoff of the five watersheds. 
Table 10. Soil hydrological groups in the five watersheds.

\begin{tabular}{lcccc}
\hline & $\begin{array}{c}\text { Sandy clay } \\
\text { loam }\end{array}$ & & $\begin{array}{c}\text { Clay } \\
\text { loam }\end{array}$ & $\begin{array}{c}\text { Rock } \\
\text { outcrop }\end{array}$ \\
\cline { 2 - 3 } $\begin{array}{l}\text { Hydrological } \\
\text { group }\end{array}$ & $\mathrm{B}$ & & $\mathrm{D}$ & $\mathrm{D}$ \\
\hline Sand (\%) & 62.95 & & 34.35 & - \\
Silt (\%) & 20.09 & & 22.26 & - \\
Clay (\%) & 16.96 & & 43.39 & - \\
Exposed rock & 0.00 & & 0.00 & 100.00 \\
\hline
\end{tabular}

shall contribute pre-dominantly to runoff without much infiltration capacity. Similarly, the texture of the soil also determines to a large extent the moisture-holding capacity of the soils and to a great extent affects the infiltration and evaporation processes that inter alia affect the surface runoff and hydrographs of the watersheds (Tansey and Millington 2001). Therefore, W1, W2 and W5 will have higher surface runoff compared to the other two watersheds because of their varying soil characteristics.

\subsubsection{Model simulations}

Figure 12 shows the simulated runoff output from each of the five watersheds. The average annual runoff statistics of each watershed is given in table 11. As per the model simulation, W5 has the highest runoff of $11.17 \mathrm{~mm} /$ year followed by $\mathrm{W} 1(7.9 \mathrm{~mm} /$ year $), \mathrm{W} 2(6.6 \mathrm{~mm} /$ year $), \mathrm{W} 4$ (5.33 mm/year) and W3 (4.29 mm/year). These results indicate that $\mathrm{W} 5$ is more vulnerable to flooding during high rain spells followed by W1, $\mathrm{W} 2$, W4 and W3, respectively. The simulated results on the hydrological responses from the five watersheds are quite in agreement with those of the morphometric analysis. Instantaneous unit hydrographs of all five ungauged watersheds were developed, using the approach (Bhat 2009). From the analysis of the hydrographs, it is revealed that W5, with highest discharge potential and lower time to hydrograph peak, is more prone to flooding as compared to other watersheds. Results also reveal that $\mathrm{W} 1$ is the next vulnerable watershed due to large surges of water discharge and consequent flooding. Again, these results are in conformity with the hydrological simulation and the morphometric results discussed above. Therefore, it is quite evident that the geomorphological, physiographic characteristics and geological setting of

Table 11. Predicted runoff as simulated by SWAT model.

\begin{tabular}{lccccc}
\hline Watersheds & W1 & W2 & W3 & W4 & W5 \\
\hline Runoff mm/year & 7.9 & 6.6 & 4.29 & 5.33 & 11.17 \\
\hline
\end{tabular}

the watershed have significant impact on its hydrological response. Therefore, geomorphological studies are a pre-requisite for understanding the hydrological response of the watersheds and can be used to predict flood peaks, sediment yield and water discharge of ungauged watersheds (Chow 1964; Gardiner 1981; Al-Wagdany and Rao 1997).

\section{Conclusions}

Even though there is growing interest in research on natural disasters among geoscientists, there is still a significant gap in our understanding of the factors associated with flood hazard vulnerability (Beven 1989). This research study conducted in various representative sites is a step in that direction. It therefore addressed the fundamental research question of assessing the geomorphic and hydrological factors that make a drainage basin more or less prone to flooding. The three-pronged approach adopted in this study for characterizing the hydrological response of five watersheds with varied topography, land use/land cover, soils and geological setting indicates the strong relationship between the geomorphological, geological and hydrological setting of the watersheds. These research outcomes show that the geomorphometric characteristics at watershed scale have a strong influence on the hydrological characteristics and are direct and credible indicators to infer hydrological information including flooding and flood vulnerability of the ungauged watersheds (Patton 1988). However, these results need to be tested in other watersheds in the Jhelum basin in order to develop a simple model relating the geomorphology with the hydrology in the Jhelum basin to predict flood peaks, sediment yield and water discharge (Chow 1964; Gardiner 1981; Viera 2003). Such an operational model, when realized, shall go a long way in mitigating and developing an early warning system for flood management in the Jhelum basin.

\section{References}

Agarwal A and Narain S 1996 Floods, floodplains and environmental myths. State of India's environment: A citizen report; Centre for Science and Environment, New Delhi.

Ahern M, Kovats S R, Wilkinson P, Few R and Matthies F 2005 Global health impacts of floods: Epidemiologic evidence; Epidemiol. Rev. 27 36-46.

Al-Wagdany A S and Rao A R 1994 Drainage network simulation using digital elevation models; Proceeding of the International Conference on Remote Sensing and GIS (India: Tata McGraw-Hill).

Al-Wagdany A S and Rao A R 1997 Estimation of the velocity parameter of the geomorphologic instantaneous unit hydrograph; Water Resour. Manage. 11 1-16. 
Arnell N 2002 Hydrology and global environmental change (Harlow, England: Prentice-Hall).

Arnold J G, Srinivasan R, Muttiah R S and Williams J R 1998 Large area hydrologic modeling and assessment Part 1: Model development; J. Am. Water Resour. Assoc. 34(1) $73-89$.

Band L E 1986 Topographic partition of watershed with digital elevation models; Water Resour. Res. 22(1) 15-24.

Bapalu V G and Sinha R 2005 GIS in flood hazard mapping: A case study of Kosi River Basin, India; www.gisdevelopment.net, Natural Hazard Management, ESRI.

Barry R G and Chorley R J 1998 Atmosphere, weather and climate (7th Edition) (London: Routledge).

Bates P D and De Roo A P J 2000 A simple raster-based model for flood inundation simulation; J. Hydrol. 236 54-77.

Berz G, Kron W, Loster T, Rauch E, Schimetschek J, Schmieder J, Siebert A, Smolka A and Wirtz A 2001 World map of natural hazards - a global view of the distribution and intensity of significant exposures; Natural Hazards 23(2-3) 443-465.

Beven K 1989 Changing ideas in hydrology - the case of physically based models; J. Hydrol. 105 157-172.

Bhat S A 2009 Geomorphological and hydrological control on flood vulnerability of Jhelum Basin; Unpublished Ph.D thesis, University of Kashmir, India.

Bhat S A and Romshoo S A 2008 Digital elevation model based watershed characteristics of upper watersheds of Jhelum basin; J. Appl. Hydrol. 21(1-2) 31-43.

Bosch J M and Hewlett J D 1982 A review of catchment experiments to determine the effects of vegetation changes on water yield and evapotranspiration; J. Hydrol. 55 3-23.

Brasington J and Richards K 1998 Interactions between model predictions, parameters and DTM scales for TOPMODEL; Comput. Geosci. 24 299-314.

Burrough P A 1986 Principles of geographic information systems for land resources assessment (UK: Oxford University Press).

Carlston C W 1963 Drainage density and stream flow; US Geological Survey Professional Report No. 422C, 67p.

Chow V T 1964 Handbook of applied hydrology (New York: McGraw-Hill).

Clark C O 1945 Storage and the unit hydrograph; Trans. Am. Soc. Civil Eng. 110 1419-1446.

Clarke J I 1966 Morphometry from maps; In: Essays in geomorphology (ed.) Dury G H (New York: Elsevier Publishing Co.), pp. 235-274.

Coates L 1999 Flood fatalities in Australia, 1788-1996; Aust. Geogr. 30(3) 391-408.

Day P R 1965 Particle fractionation and particle-size analysis; In: Methods of soil analysis, Part 1 (ed.) Black C A (Madison, Wisconsin: American Society of Agronomy, Inc.), pp. 545-567.

DeVantier B A and Feldman A D 1993 Review of GIS applications in hydrologic modelling; J. Water Resour. Plan. Manage. 119(2) 246-261.

Dhar O N, Mandal B N and Kulkarni A K 1982 Effect of the Pir Panjal range of Himalayas over monsoon rainfall distribution in Kashmir Valley; Proc. Int. Symp. hydrological aspects of mountainous watersheds, Vol. 1, Roorkee, India.

Entekhabi D, Asrar G R, Betts A K, Beven K J, Bras R L, Duffy G J, Dunne T, Koster R D, Lettenmaier D P, McLaughin D B, Shuttleworth W J, Van Genuchten M T, Wei M Y and Wood E F 1999 An agenda for land surface hydrology research and call for the second international hydrological decade; Bull. Am. Meteorol. Soc. 80(10) 2043-2058.
Fohrer N, Haverkamp S, Eckhardt K and Frede G G 2001 Hydrologic response to land use changes on the catchment scale; Phys. Chem. Earth 26(7-8) 577-582.

Foody G M 2002 Status of land cover classification accuracy assessment; Remote Sens. Environ. 80(1) 185-201.

Fu K S 1976 Pattern recognition in remote sensing of the Earth resources; IEEE Trans. Geosci. Electron. 14 10-11.

Garbrecht J and Martz L W 1997 The assignment of drainage direction over flat surfaces in raster digital elevation models; J. Hydrol. 193 204-213.

Gardiner V 1981 Drainage basin morphometry; In: Geomorphologieal techniques (ed.) Goudie A (London, UK: Allen and Unwin), pp. 47-55.

Gorokhovich Y, Khanbilvardi R, Janus L, Goldsmith V and Stern D 2000 Spatially distributed modeling of stream flow during storm events; J. Am. Water Resour. Assoc. 36(3) 523-539.

Green W H and Ampt G A 1911 Studies on soil physics-I. The flow of air and water through soils; J. Agric. Sci. 4 11-24.

Hajat S, Ebi K L, Kovats S, Menne B, Edwards S and Haines A 2003 The human health consequences of flooding in Europe and the implications for public health; J. Appl. Environ. Sci. Public Health 1 13-21.

Hamlet A F and Lettenmaier D P 1999 Effects of climate change on hydrology and water resources in Columbia River basin; J. Am. Water Resour. Assoc. 35(6) 15971623.

Hansen M, Dubayah R and DeFries R 1996 Classification trees: An alternative to traditional land cover classifiers; Int. J. Remote Sens. 17 1075-1081.

Horton R E 1932 Drainage basin characteristics; Trans. Am. Geophys. Union 13 350-361.

Horton R E 1945 Erosional development of streams and their drainage basins, hydrological approach to quantitative morphology; Bull. Geophys. Soc. Am. 56 275-370.

Hudson P F and Colditz R R 2003 Flood delineation in a large and complex alluvial valley, lower Panuco basin, Mexico; J. Hydrol. 280 229-245.

IPCC 2007 Climate change, impacts, adaptation and vulnerability; In: Contribution of Working Group II to the fourth assessment report of the intergovernmental panel on climate change (eds) Parry $\mathrm{M} \mathrm{L}$, Canziani O F, Palutikof J P, van der Linden $\mathrm{P} \mathrm{J}$ and Hanson $\mathrm{C} \mathrm{E}$ (Cambridge UK: Cambridge University Press).

Jack D I 2004 Himalayan perceptions: Environmental change and the well-being of mountain people; Himalayan J. Sci. 2(3) 17-19.

Jain V and Sinha R 2003 Evaluation of geomorphic control on flood hazard through geomorphic instantaneous unit hydrograph; Curr. Sci. 85(11) 1596-1600.

Jensen J 1996 Introduction to digital image processing: A remote sensing perspective, 1st edn (New York, US: Prentice Hall).

Jonkman S N 2005 Global perspectives of loss of human life caused by floods; Natural Hazards 34 151-175.

Jonkman S N and Kelman I 2005 An analysis of the causes and circumstances of flood disaster deaths; Disasters 29(1) $75-97$.

Jonkman S N and Vrijling J K 2008 Loss of life due to Floods; J. Flood Risk Manage. 1 43-56.

Khan S and Romshoo S A 2008 Integrated analysis of geomorphic, pedologic and remote sensing data for digital soil mapping; J. Himalayan Ecol. Sustain. Develop. 3(1) 11-19.

Kull D W and Feldman A D 1998 Evolution of Clark's unit graph method to spatially distributed runoff; J. Hydrol. Eng. 3(1) 9-19. 
Lawrence W M and Jurgen G 1993 Automated extraction of drainage network and watershed data from digital elevation models; J. Am. Water Resour. Assoc. 29(6) 901-908.

Lillesand T M and Kiefer R W 1987 Remote sensing and image interpretation (New York: John Wiley \& Sons).

Mark D M 1988 Network models in geomorphology; In: Modelling in geomorphological systems (ed.) Anderson M G (Chichester: John Wiley), pp. 73-97.

Matheussen B, Kirschbaum R L, Goodman I A, O'Donnell G M and Lettenmaier D P 2000 Effects of land cover change on stream flow in the interior Columbia river basin (USA and Canada); Hydrol. Process. 14(5) 867-885.

Melton M A 1957 An analysis of the relations among the elements of climate, surface properties and geomorphology; Technical Report 11, Department of Geology, Columbia University, New York.

Montgomery D R and Dietrich W E 1989 Source areas, drainage density and channel initiation; Water Resour. Res. 25 1907-1918.

Montgomery D R and Dietrich W E 1992 Channel initiation and the problem of landscape scale; Science 255 826-830.

Moonis R, Aijazuddin A and Ali M 1975 The valley of Kashmir: A geographical interpretation (New Delhi: Vikas Publishing House), pp. 95-99.

Munich Re 2007 Natural catastrophes 2007 analyses, assessments and positions. Munich Re Topics Geo series publication (Munich, Germany: Munich Reinsurance Company).

Oky P, Ardiansyah D and Yokoyama R 2002 DEM generation method from contour lines based on the steepest slope segment chain and a monotone interpolation function; ISPRS J. Photogram. Remote Sens. 57(1-2) 86-101.

Olivera F and Maidment D R 1996 Runoff computation using spatially distributed terrain parameters; Proc. ASCE - North American Water and Environment Congress, June 22-28, Anaheim California, US.

Patton P C 1988 Drainage basin morphometry and floods; In: Flood geomorphology (eds) Baker V R, Kochel R C and Patton P C (New York: John Wiley), pp. 51-64.

Quilbe R, Rousseau A N, Moquet J S, Savary S, Ricard S and Garbouj M S 2008 Hydrological response of a watershed to historical land use evolution and future land use scenario under climate change conditions; Hydrol. Earth Syst. Sci. 12 101-110.

Rakesh K, Lohani A K, Sanjay C C and Nema R K 2000 GIS based morphometric analysis of Ajay river basin up to Sararath gauging site of south Bihar; J. Appl. Hydrol. 14(4) 45-54.

Robinson M, Boardman J, Evans R, Heppell K, Packman J and Leeks G 2000 Land use change; In: The hydrology of the UK: A study of change (ed.) Acreman M (New York: Routledge), pp. 30-54.

Romshoo S A 2004 Geostatistical analysis of soil moisture measurements and remotely sensed data at different spatial scales; Environ. Geol. 45 339-349.

Saghafian B, Julien P and Rajaie H 2000 A spatial traveltime method for watershed routing; 4th International con- ference on integrating GIS and Environmental Modeling (GIS/EM4), Canada, September 2-8, 2000.

Singh S 1972a Altimetric analysis: A morphometric technique of landform study; Nat. Geogr. 7 59-68.

Singh S 1972b Concept of periglacial processes; Deccan Geogr. 10(2) 71-79.

Strahler A N 1964 Quantitative geomorphology of drainage basins and channel networks; In: Handbook of applied hydrology, Section 4.39-4.76 (ed.) Chow V T (New York: MacGraw-Hill).

Tansey K J and Millington A C 2001 Investigating the potential for soil moisture and surface roughness monitoring in dry lands using ERS SAR data; Int. J. Remote Sens. 22(11) 2129-2149.

Tarboton D G 1989 The analysis of river basins and channel networks using digital terrain data; D.Sc. Thesis, M.I.T., Cambridge, MA.

Tarboton D G 1997 A new method for the determination of flow directions and contributing areas in grid digital elevation models; Water Resour. Res. 33(2) 309-319.

Tarboton D G and Ames D P 2001 Advances in the mapping of flow networks from digital elevation data; Proc. World Water and Environmental Resources Congress, Orlando, Florida, May 20-24, ASCE.

Tarboton D G and Shankar U 1998 The identification and mapping of flow networks from digital elevation data; Proc. AGU Fall Meeting, San Francisco, December 6-10.

Tarboton D G, Bras R L and Rodriguez-Iturbe I 1991 On the extraction of channel networks from digital elevation data; Hydrol. Process. 5(1) 81-100.

Tarboton D G, Bras R L and Rodriguez-Iturbe I 1992 A physical basis for drainage density; Geomorphology $\mathbf{5}(\mathbf{1} / \mathbf{2}) 59-76$.

Timothy D, Straub C, Melching S and Kyle E K 2000 Equations for estimating Clark unit hydrograph parameters for small rural watersheds in Illinois; USGS Water Resources Investigation Report No. 2000-4184, US.

Toogood J A 1958 A simplified textural classification diagram; Canadian J. Soil Sci. 38 54-55.

Tucker G E and Bras R L 1998 Hill slope processes, drainage density and landscape morphology; Water Resour. Res. 34(10) 2751-2764.

UN 2004 Guide lines for reducing flood losses (2nd edn) Geneva.

USDA Soil Conservation Service 1972 National Engineering Handbook, Section IV: Hydrology (NEH-4), Washington DC, US.

Viera F de la C 2003 Geomorphology and natural hazards of the Saamala river basin in Guatemala; ITC International Institute for Geoinformation Science and Earth Observation M.Sc. Thesis 2003, Enschede, The Netherlands.

Ward R C and Robinson M 2000 Principles of hydrology (4th edn) (Maidenhead: McGraw-Hill).

Willgoose G 1996 A statistic for testing the elevation characteristics of landscape simulation models; J. Geophys. Res. 99(13) 987-996.

Yildiz O 2004 An investigation of the effect of drainage density on hydrological response; Turkish J. Eng. Environ. Sci. 28 85-94. 